ILLINOIS

NATURAL

HISTORY

S URVEY

\title{
A Revision of the Bees of the Genus Andrena of the Western Hemisphere
}

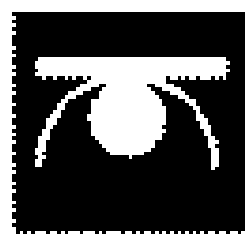

\section{Part XIV}

Subgenus Onagrandrena

Wallace E. LaBerge and Robbin W. Thorp

\section{Part XV}

Subgenus Hesperandrena

Robbin W. Thorp and Wallace E. LaBerge

Illinois Natural History Survey Bulletin

Volume 37, Articles 1 and 2

March 2005 
Illinois Natural History Survey, David L. Thomas, Chief

A Division of the Illinois Department of Natural Resources

\author{
Illinois Natural History Survey \\ Distribution Office \\ 607 E. Peabody Dr. \\ Champaign, IL 61820
}

Citation:

Thorp, Robbin W., and Wallace E. LaBerge. 2005. A revision of the bees of the genus Andrena of the Western Hemisphere. Part XIV - Subgenus Onagrandrena and Part XV-Subgenus Hesperandrena.Illinois Natural History Survey Bulletins 37(1):1-64 and 37(2):65-94.

\title{
Editor: Charles Warwick
}

\section{US ISSN 0073-4918}

Printed by authority of the State of Illinois

P0057479-.65M-03-05

Printed with soy ink on recycled and recyclable paper.

Equal opportunity to participate in programs of the Illinois Department of Natural Resources (IDNR) and those funded by the U.S. Fish and Wildlife Service and other agencies is available to all individuals regardless of race, sex, national origin, disability, age, religion, or other non-merit factors. If you believe you have been discriminated against, contact the funding source's civil rights office and/or the Equal Employment Opportunity Officer, IDNR, One Natural Resources Way, Springfield, IL 62702-1271; 217/785-0067; TTY 217/782-9175. 
ILLINOIS

NATURAL

HISTORY

S URVEY

\section{A Revision of the Bees of the Genus Andrena of the Western Hemisphere Part XV. Subgenus Hesperandrena}

Robbin W. Thorp and Wallace E. LaBerge 


\section{CONTENTS}

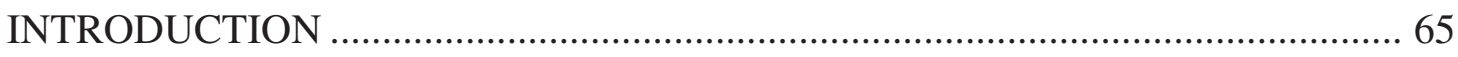

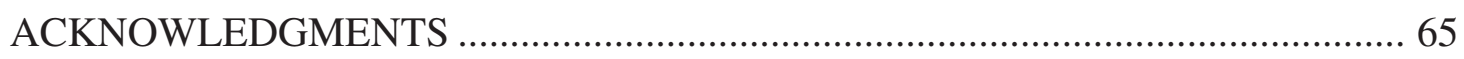

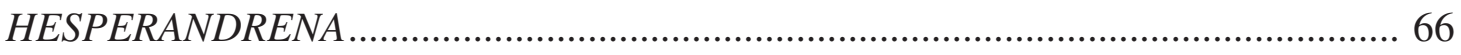

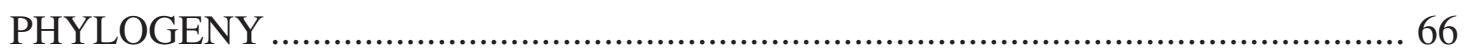

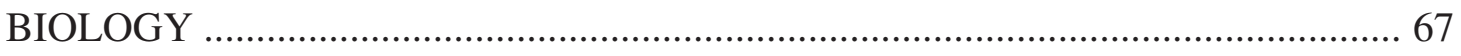

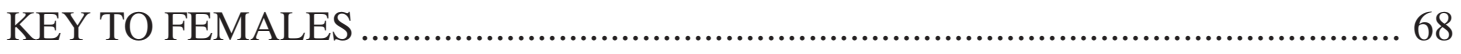

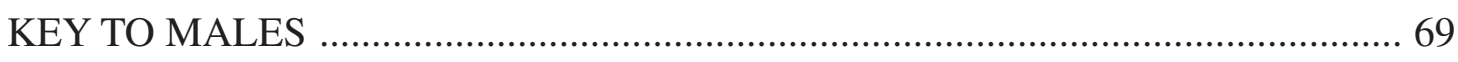

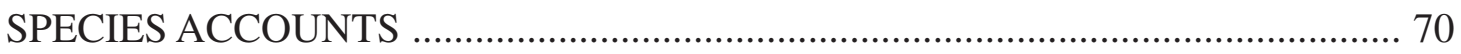

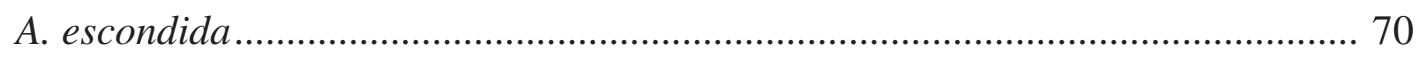

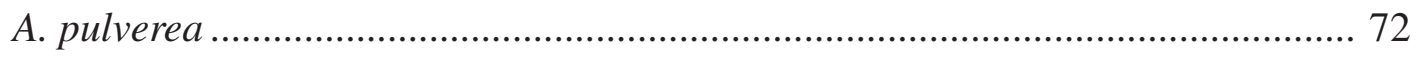

Fig. 1. Distribution Maps of A. pulverea, escondida, and duboisi ......................... 73

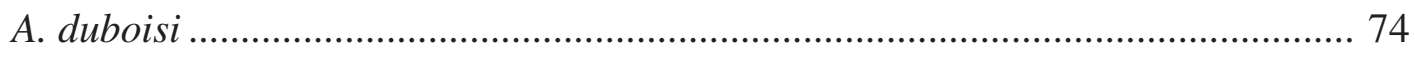

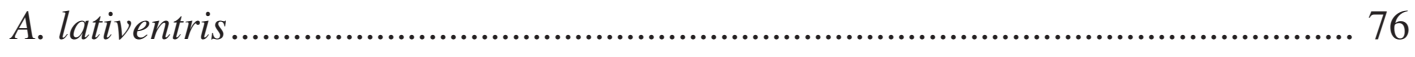

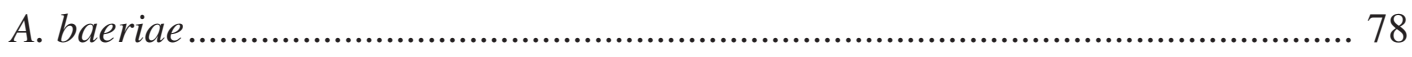

Fig. 2. Distribution Maps of A. lativentris, baeriae, and eremophila..................... 79

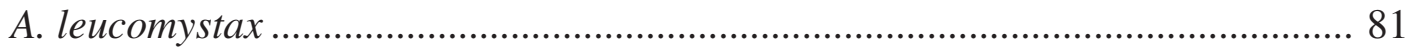

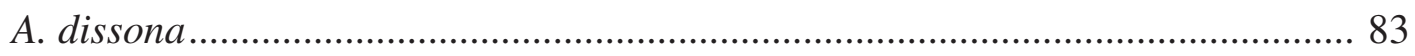

Fig. 3. Distribution Maps of A. leucomystax, dissona, and compositarum ............ 84

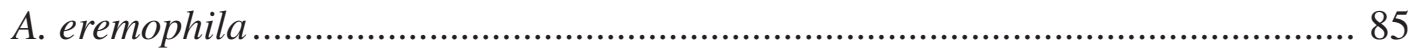

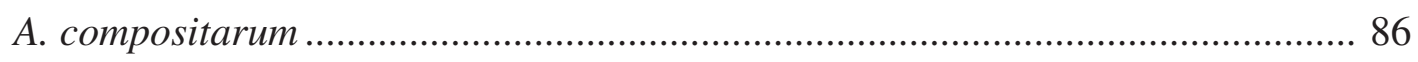

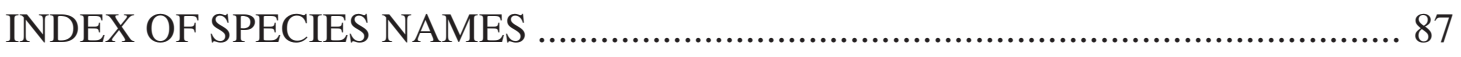

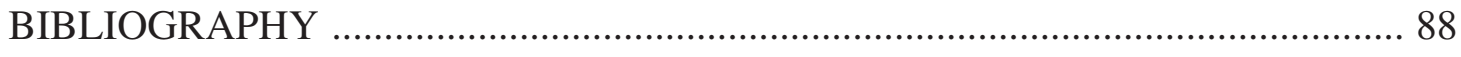

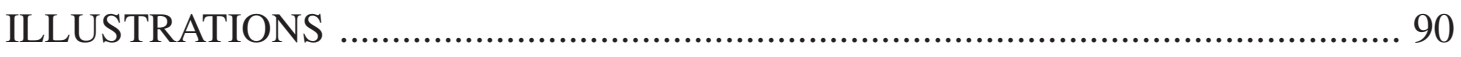




\begin{abstract}
This work reports on a study of 1,200 specimens segregated into 9 species, 4 of which are new to science. One name is relegated to synonymy. The relationships within the subgenus and with other subgenera of Andrena are briefly discussed.
\end{abstract}

\title{
INTRODUCTION
}

The subgenus Hesperandrena was recognized and described by Timberlake in Lanham 1949 (p. 208) to include two previously described species, Andrena escondida Cockerell and Andrena baeriae Timberlake. These two species have in common a propodeum which Timberlake described as having the dorsal surface, “... broad, gently curved and inclined from base to apex, without definite truncation, the lateral margins distinctly carinate and convexly arcuate." This is the main character separating this subgenus (Fig. 4) from other subgenera of Andrena except that in the males of Hesperandrena the lateral margins of the propodeum are not carinate. Other characters are given in the description of the subgenus below. The species of this subgenus are very similar to one another and difficult to tell apart. The species are known only from California and Baja California.

The reader is referred to earlier sections of this revision (LaBerge 1967, 1969, 1971, 1973, 1977, 1980, 1986, 1987, 1989; LaBerge and Bouseman 1970, 1987; LaBerge and Ribble 1972, 1975; Bouseman and LaBerge 1979; Thorp 1969; Donovan 1977) for details of morphology and a more complete bibliography on the genus Andrena. No new terms have been introduced and the bibliography presented here includes only references cited. Published locality and floral records are included in the sections at the end of each species account. Institutions with type material are listed with contractions as follows:

AMNH-American Museum of Natural History, New York City

CAS - California Academy of Science, San Francisco

INHS-Illinois Natural History Survey, Champaign

LACM-Los Angeles County Museum (of Natural History), Los Angeles

PANS_Philadelphia Academy Natural Sciences

USNM-United States National Museum (of Natural History), Washington, D.C.

UCB-University of California at Berkeley (Entomology Collection)

UCD_-University of California at Davis (Entomology Collection)

UCR-University of California at Riverside (Entomology Collection)

UKL-University of Kansas, Lawrence

USU_Utah State University, Logan

\section{ACKNOWLEDGMENTS}

This work would not have been completed without the long-term support of the National Science Foundation for most years between 1959 and 1985. The last of these grants was BSR 82-07173. The Bohart Museum of Entomology, University of California at Davis and Robbin and Joyce Thorp are thanked for helping the junior author spend two weeks in Davis, California, during which time the bees of the Bohart Museum, the California Academy of Sciences, and the University of California at Berkeley were reviewed, and the holotypes of the California Academy were studied.

The authors wish to thank the persons in charge of the collections at the Smithsonian Institution, Washington, D.C. and the American Museum of Natural History for allowing us to study types in their care. Specimens were borrowed, often for long periods of time, from the collections listed below and special thanks are extended to these persons and collections. 
Terry Griswold, U.S. Pollinating Insect Collection, Bee Biology and Systematics Laboratory, Utah State University, Logan; Lynn S. Kimsey, the Bohart Musuem of Entomology, University of California at Davis; John Chemsak, Essig Museum of Entomology, University of California at Berkeley; R.R. Snelling, Los Angeles County Museum of Natural History, Los Angeles; Robert Brooks, Snow Entomological Museum, University of Kansas, Lawrence; Ronald J. McGinley, U.S. National Museum of Natural History, Washington, D.C.; U.N. Lanham, University of Colorado Museum, Boulder; Daniel Otte, Academy of Natural Science, Philadelphia; Floyd G. Werner, Department of Entomology Collection, University of Arizona, Tucson; J.E.H. Martin, Canadian National Collection, Ottawa; and the late George Eickwort, Insect Collection, Cornell University, Ithaca, N. Y.

\section{Subgenus HESPERANDRENA Linsley and MacSwain}

Hesperandrena Timberlake, 1949, in Lanham, 1949, Univ. California Pub. Ent., 8:208; LaBerge, 1964, Univ. Nebraska St. Mus. Bull., 4:301; 1986, Trans.American Ent. Soc., 111:443, 447, 452.

Bees of the subgenus Hesperandrena are small to medium with short malar spaces, short vertices (never taller than one ocellar diameter and mostly shorter), and genal areas of moderate width. Both sexes have relatively weak sculpturing, propodeal dorsal areas smooth with small, sparse punctures, and the terga with weak but distinct pale apical fasciae. The females have the propodeal corbicula developed but with internal hairs and scopal hairs that are moderate in length and weakly branched or simple. The males may or may not have subapical sternal fimbriae. We believe the flattened branchless hairs on sternum 7 to be a unique character found only in males of Hesperandrena.

Common Characters. Small to medium-sized bees; facial quadrangle quadrate to slightly wider than long; eyes with inner margins parallel to converging slightly towards mandibles; vertex above lateral ocellus usually equals less than one ocellar diameter; genal area as broad as eye in profile or slightly broader; galea broad with concave lateral margin, exceeded by one maxillary palpal segment or slightly more or less; labral process simple or bidentate, often shallowly emarginate; cheeks moderately broad, rounded behind.

Female. Facial fovea large, shallow; subgenal coronet present. Propodeal corbicula present, with well formed, long, dorsal hairs, usually with internal plumose hairs. Trochanteral flocculus present but usually sparse. Tibial scopal hairs moderately long, usually weakly branched.

Male. Antennae short, female-like, first segment usually longer than second. Sterna with subapical fimbriae; sternum 7 with apical lobe deeply emarginate; sternum 8 with area basal to expanded apex with flat, broad hairs with attenuate apices (Fig. 9).

\section{PHYLOGENY}

The phylogeny of the subgenus Hesperandrena is not clearly understood at present and additional work is obviously needed. We assume that the subgenus is closely related to the subgenera Larandrena, Andrena s. str., Opandrena, Ptilandrena, and Leucandrena. All of these subgenera have species occuring today on the west coast where the Hesperandrena probably originated and all share in the modified pronotum with lateral angles and ridges usually being present. We believe the Hesperandrena to be especially similar to, and perhaps most closely related to the Larandrena and Ptilandrena. 


\section{BIOLOGY}

Females of Hesperandrena appear to be oligolectic, most on Asteraceae but one species, A. pulverea, on flowers of Limnanthaceae. Because most of the Hesperandrena live in association with vernal pool ecosystems in California, the Hesperandrena are becoming recognized as an important group in conservation planning and mitigation issues. These species provide an important ecological service in pollination of showy flowers in vernal pool communities.

Distribution and Abundance. Hesperandrena is predominantly a California subgenus with one species reaching northern Baja California in Mexico (Thorp and Leong, 1998). Most are abundant when the showy displays of their pollen plants, Lasthenia (goldfields) or Limnanthes (meadowfoam), bloom in early spring.

Overwintering, Emergence, and Flight Season. Species of Hesperandrena have annual life cycles and emerge in early spring in association with bloom of their pollen plants (Thorp, 1990). They fly from early March into early July but are most abundant in March and April. Circumstantial evidence for the ability to delay emergence for a year during severe drought conditions is presented for A. pulverea Viereck (as limnanthis Timberlake) by Thorp (1990).

Male Behavior. Most species of the genus exhibit proterandrey, i.e., males emerge before females. Males often cruise the pollen host plants of females, but some also cruise clustered nests.

Nest-sites, Architecture, and Construction. The nests of Hesperandrena are shallow, 7.5 to $10.2 \mathrm{~cm}$ deep, especially in vernal pool ecosystems where soil is shallow and the water table high. The burrows are typically L-shaped with a single brood cell at the end of each short lateral. There is usually more than one lateral per burrow, with each lateral filled after the egg is laid and the cell capped. Fill presumably comes from the succeeding lateral. Details of brood cells, pollen mass formation, cell cap, egg, and early larval position are figured in Thorp (1990). Brood cells are lined with a waxlike material. Pollen is deposited in the bottom of the cell and worked into a spherical mass with the addition of nectar. An egg is then deposited atop the mass. The larva ecloses from the egg, feeds, and progresses through its development during the spring. By summer it has reached the post-defecating stage and remains thus until autumn. During the autumn the larva pupates and transforms into an adult, but remains in the brood cell over the winter. The adult emerges in spring in synchrony with bloom of its pollen-host plant.

Flower Relationships. Females are mostly oligolectic on Asteraceae, especially Lasthenia (Thorp and Leong, 1995). One species, A. pulverea (as limnanthis), is an oligolege of Limnanthes (Limnanthaceae) (Thorp and Leong, 1995). Using three colors of pantraps to sample bees in patches of the white-flowered Limnanthes douglasii R. Br. var. rosea (Benth.) C. Mason, Leong and Thorp (1999) found that females of A. pulverea (as limnanthis) were most frequently trapped about equally in white and blue pans, while males were trapped predominantly in white pans. Yellow pans produced significantly lower captures of both sexes of this species. Other Andrena, especially those that are oligoleges of yellow flowers were most frequently trapped in the yellow pans. The females of A. pulverea were the most common bees found in patches of Limnanthes by Leong and Thorp (1990). The foraging patterns of Hesperandrena, especially females foraging for pollen, may influence genetic structure of pollen-host populations through near-neighbor, bee-mediated pollen flow (Thorp, 1999).

Pollen Competition. Two or more species of Hesperandrena often occur together (Thorp and Leong, 1998). Because they forage for pollen on different hosts, no resource overlap occurs between A. pulverea (as limnanthis) and other species of Hesperandrena. Nevertheless, pollen resources are often shared by multiple species that are sympatric and oligolectic on Lasthenia. 
Parasites, Predators, and Associates. Strepsiptera: Stylopidae. Female Stylops have been found between the abdominal terga of species of Hesperandrena. Hymenoptera: Anthophoridae. Females of cuckoo bees of the genus Nomada have been observed in the vicinity of nests of Hesperandrena (R. W. Thorp personal observation).

Chromosome Number. Chromosome numbers for Hesperandrena are unusually low for bees. Goodpasture (1974) found numbers of $\mathrm{n}=10$ for A. (Hesperanda) sp. (probably dissona Thorp and LaBerge) and $\mathrm{n}=3$ for $A$. duboisi Timberlake. He compared the karyotypes of the two Hesperandrena and found that the total genome length in duboisi was half that in dissona, the other species he studied.

Role in Conservation. Vernal pool ecosystems are threatened in California. The important role of pollen-specialist solitary bees, especially Andrena (Hesperandrena) and A. (Diandrena), as pollinators of many of the characteristic showy flowers and the need to protect these bees to continue their ecological service contributions have been stressed by Thorp $(1976,1990)$ and Thorp and Leong $(1995,1998)$. Females of Hesperandrena species are oligoleges of sensitive plants: A. pulverea on Limnanthes vinculans Ornduff (federally and state listed as endangered), and A. [species? (probably duboisi and dissona)] on Lasthenia conjugens Greene (Thorp personal observation). Both plants are endemic to California and are placed on List 1B (plants rare, threatened, or endangered in California and elsewhere) by the California Native Plant Society (Skinner and Pavlik 1994). These bee species are likely to be important pollinators of their endangered plant hosts and therefore part of the critical habitat necessary for the reproduction and perpetuation of the plants.

\section{Key to the Females of} Hesperandrena

1. Scopal hairs short, hind tibia broad, subcuneate; labral process usually about as long as basal width, no less than three-fourths as long as wide; tergal apical fasciae narrow, ................................ pulverea Viereck

Scopal hairs uniformily long, hind tibia not broadened; labral process much shorter than its basal width, often half or less as long as broad; tergal apical fasciae often broad

2(1). Dorsal thoracic hairs mostly short; facial fovea broad above, separated from lateral ocellus by half an ocellar diameter or slightly more or less ....................................................... latis Timberlake

Dorsal thoracic hairs mostly long; facial fovea narrow above, separated from lateral ocellus by one ocellar diameter or slightly more $\ldots \ldots \ldots \ldots \ldots \ldots \ldots . . . . .3$.

3(2). Mesoscutum anteriorly, mesepisternum, face below ocelli, and abdomen with metallic greenish reflection ............................................................... 4.

Mesoscutum and usually abdomen and face black, without metallic reflections

4(3). Mesoscutum posteromedially shiny, tessellation weak or absent, punctures distinct; pronotum with humeral angle and ridge distinct; forewings narrowly clouded near tips ............................. leucomystax $\mathrm{n} . \mathrm{sp}$.

Mesoscutum posteromedially usually dull, tessellate, punctures shallow, indistinct; pronotum with distinct humeral angle and dorsolateral ridge indistinct, especially below; forewings not clouded apically duboisi Timberlake

5(3). Metasomal terga 1-3 with basal areas moderately shiny, shagreening coarse, especially apically, but not completely dulling surface; clypeus with basal 
half or slightly more with distinct punctures, apical third to half coarsely or punctatorugose................................... eremophila $\mathrm{n} . \mathrm{sp}$.

Metasomal terga 1-3 with basal areas dull, shagreening fine and dense, surfaces dull; clypeus with basal three-fourths or more with punctures fine, sparse, scarcely visible, apical fourth or less more coarsely......... punctate

6(5). Facial fovea with tomentum largely dark brown; mesoscutum and scutellum with hairs golden to brown; pronotal angle and ridge present but weak ...... ................................................. compositarum $\mathrm{n}$. $\mathrm{sp}$. Facial fovea with tomentum silvery; mesoscutum without brown hairs, white to pale ochraceous; pronotal angle and ridge present and distinct or absent

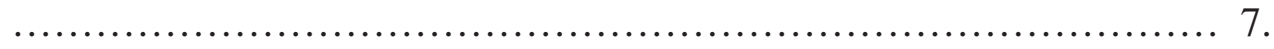

7(6). Pronotum with distinct humeral angle and dorsolateral ridge.............. 8. Pronotum without humeral angle or ridge escondida Cockerell

8(7). Mesoscutum tessellate, just mesad of parapsidal line punctures shallow, small, indistinct, obscured by dense fine tessellation, not at all shiny posteromedially; scutellum dulled by tessellation............ baeriae Timberlake Mesoscutum shinier, punctures distinct, not at all obscured by tessellation, often shiny and untessellate at least posteromedially; scutellum usually shiny to moderately so, tessellation weak or lacking at least medially......... dissona $\mathrm{n} . \mathrm{sp}$.

\section{Key to the Males of Hesperandrena}

1. Sterna 2-5 with subapical fimbriae of extremely short, moderately dense,

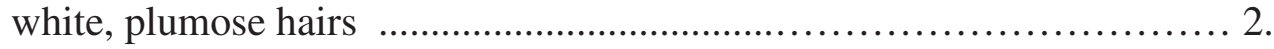
Sterna 2-5 with subapical fimbriae of long straight hairs, long curled hairs, or without fimbriae

2(1). Pronotum with distinct lateral angles and ridges; clypeus with dense beard of long, plumose, white hairs hiding surface; scutellum shiny at least medially, mesoscutum often shiny posteromediall .............. leucomystax $\mathrm{n}$. sp.

Pronotum with pronotal angles weak, lateral ridges not extending below diagonal pronotal suture; clypeus with long, pale, plumose hairs, but hairs relatively sparse; scutellum and mesoscutum dulled by fine dense tessellation duboisi Timberlake

3(1). Sterna 2-5 lacking subapical fimbriae ................... pulverea Viereck Sterna 2-5 with subapical fimbriae of long, straight or curled, pale hairs ...... 4.

4(2). Sterna 2-5 with subapical fimbriae of dense, long, white, straight, plumose hairs; pronotum without lateral angles or dorsolateral ridges escondida Cockerell.

Sterna 2-5 with subapical fimbriae of relatively sparse, extremely long, pale downwards curled hairs; pronotum often with lateral angles and ridges 
5(4). Clypeus dark, without yellow or cream-colored macula 6.

Clypeus entirely pale or with large mediobasal, yellow or cream-colored. macula 7.

6(5). Pronotal lateral carina sharply defined, extending from humeral angle to ....... bottom of pronotum ....................................... baeriae Timberlake Pronotum with lateral carina weakly defined, extends ventrad to diagonal pronotal suture ........................................ compositarum $\mathrm{n} . \mathrm{sp}$.

7(5). Integument with metallic green reflections, especially on face and anterior third of mesoscutum; terga 2 and 3 rarely with pale brown lateral patches dissona $\mathrm{n} . \mathrm{sp}$.

Integument black, without metallic green reflections; terga 2 and 3 often with small, pale brown, lateral patches. lativentris Timberlake

\section{SPECIES ACCOUNTS}

\section{Andrena escondida Cockerell}

Andrena escondida Cockerell, 1938, Ann. Mag. Nat. Hist., ser. 11, 2:146.

Andrena (Hesperandrena) escondida: Timberlake, 1949, in Lanham, California

Univ. Publ. Ent., 8:208; Timberlake, 1951, Proc. United States Nat. Mus., 101:386 Rust, Menke and Miller, 1985, Entomology of the California Channel

Islands: Proc. 1st Symp., San Diego, California, Dec. 1981, p. 42.

This small species with black integument can be recognized in the female sex by the lack of pronotal humeral angles and dorsolateral ridges, the short labral process, and the relatively strongly punctate mesoscutum. The male of escondida has the clypeus black, lacks pronotal humeral angles, and has well-formed, sternal, subapical fimbriae of relatively long, dense, straight hair

FEMALE: Measurements and Ratios. $\mathrm{N}=12$; length, 8.0-9.5 mm; width, 2.0-2.5 $\mathrm{mm}$; WL, $\mathrm{M}=2.61 \pm 0.189 \mathrm{~mm}$; FL/FW, $\mathrm{M}=0.95 \pm 0.029$; FOVL/FOVW, $\mathrm{M}=2.60 \pm 0.157$.

Integumental Color. Black except as follows: mandible with apical third rufescent; flagellum with last several segments reddened below; wing membranes hyaline, veins red to reddish brown; metasomal terga with apices narrowly hyaline, becoming darker towards base; tibial spurs yellow.

Structure. Antennal scape as long as first three and one-half flagellar segments or slightly more; flagellar segment 1 as long as segments 2 plus 3, which are equal in length; segments 5-7 about as long as broad. Eyes each about four times as long as broad, inner margins parallel. Mandibles short, overlapping when closed by one fourth or less of mandibular length; with subapical tooth. Malar space short, linear. Galea pointed, outer margin gently concave in apical half; surface dulled by fine tessellation. Maxillary palpus relatively short, when extended surpasses galea by about last segment, segmental ratio about as 0.7:1.0:0.9:0.6:0.5:0.6. Labial palpus normal, segmental ratio about as 1.0:0.6:0.3:0.5. Labral process short, entire, about three times as long as broad, not emarginate apically or only extremely shallowly so; shiny; labrum apical to process at least as long as process, flat, shagreened. Clypeus short, gently rounded from side to side, surface dull, tessellate with sparse, indistinct punctures, which become crowded and more distinct in narrow apical band. Supraclypeal area dull, coarsely tessellate. Face above antennal fossae 
with fine longitudinal rugulae and shagreening. Facial fovea extends to just below line across lower margins of antennal fossae, three times as long as broad; separated from lateral ocellus by about one ocellar diameter. Vertex above lateral ocellus short, equals less than one ocellar diameter. Genal area in profile equals about one and one-third times width of eye, surface dull, shagreened. Pronotum without humeral angles or lateral ridges, surface dull, shagreened.

Mesoscutum dull, finely tessellate, with punctures medially separated mostly by two or more puncture widths, near parapsidal lines and in anterior fifth or more; dorsal enclosure of propodeum finely punctatorugose basally, outside of enclosure tessellate with scattered obscure punctures; basal sulcus almost parallel-sided, short; dorsoposterior surface separated from lateral surfaces by distinct carinae. Pleurae dull, finely tessellate, punctures absent or obscure.

Metasomal tergum 1 tessellate, somewhat more finely so in apical area, with minute obscure punctures not much larger than tesserae, separated by two to four puncture widths. Terga 2-4 similarly sculptured, tergum 5 more densely punctate. Pygidial plate U-shaped, raised rim, if present, extremely narrow. Sterna 2-5 with basal areas finely tessellate, slightly shiny, with distinct punctures separated by half to two puncture widths.

Vestiture. White to pale ochraceous except as follows: facial fovea with tomentum silvery white to entirely white in lower half and pale yellow to golden in upper half; terga 5 and 6 with mediobasal hairs dark ochraceous; inner surfaces of tarsi light yellow. Dorsal thoracic hairs long, mostly longer than width of flagellum. Tergum 2 with apical fascia of pale hairs interrupted medially by less than one-third width of tergum; terga 3 and 4 with complete apical pale fasciae. Tibial scopal hairs simple to weakly plumose; propodeal corbicula incomplete anteriorly with long internal hairs; trochanteral flocculus complete but relatively sparse.

MALE: Measurements and Ratios. $\mathrm{N}=16$; length, 7-9 mm; width, 1.5-2.5 mm; $\mathrm{WL}, \mathrm{M}=2.30 \pm 0.633 \mathrm{~mm} ; \mathrm{FL} / \mathrm{FW}, \mathrm{M}=1.02 \pm 0.008 ; \mathrm{FS} 1 / \mathrm{FS} 2, \mathrm{M}=2.06 \pm 0.043$.

Integumental Color. As in female except terga 2-5 with apical areas more broadly hyaline apically.

Structure. Antennae short, female-like; flagellar segment 1 twice as long as segment 2 or slightly longer, segment 2 usually slightly longer than 3, broader than long, segments 4-7 about as long as broad; scape length as in female. Eyes each almost four times as long as broad, inner margins diverging towards vertex. Mandibles apposite, short, with subapical tooth. Galeae as in female. Maxillary palpus as in female but ratio about as 0.7:1.0:0.6:0.6:0.5:0.6. Labial palpus as in female but ratio about as 1.0:0.5:0.4:0.5. Labral process short, more than twice as broad as long, apical margin gently concave, surface shiny; labrum apical to process about as long as process, finely shagreened. Clypeus sculptured as in female but punctures slightly more distinct and denser, separated mostly by one to two puncture widths. Supraclypeal area, face above antennal fossae, and vertex and genal area as in female.

Pronotum as in female. Thoracic sculpturing as in female except as follows: anterior fifth of mesoscutum with punctures sparse, mostly separated by two puncture widths; propodeum with dorsoposterior and lateral surfaces separated by weak carinae extending up from below to about half the length of propodeum.

Metasomal terga 1-6 sculptured as in female terga 1-5 but surfaces slightly shinier. Sterna as in female. Sterna 7 and 8 as in Figs. 20 and 21. Note that sternum 7 has apical lobes evenly rounded on external edges and median emargination narrow. Sternum 8 has apex not at all emarginate or extremely shallowly so, area of broad, flattened hairs covering half or more of neck.

Vestiture. Generally white to pale ochraceous but inner surfaces of tarsi pale yellow. Metasomal terga 2-5 with weak short apical pale fasciae, those on terga 2 and 3 interrupted 
medially and often on tergum 4. Sterna 2-5 with distinct pale subapical fimbriae of long, almost straight, dense, plumose, white hairs.

Type Material. The holotype male of escondida (CAS 15,331) was collected at Rancho Escondido, Santa Catalina Island, Los Angeles Co., California, from flowers of Encelia californica, March 31, 1938, by W.P. Cockerell.

Distribution. Andrena escondida is known (Fig. 1) from Yolo County in central California south to San Diego County. It has been collected from March 2 through May 12, but chiefly in March and April. A total of 12 females and 16 males from localities listed below (including localities cited in the literature) were studied.

CALIFORNIA. ALAMEDA CO.: Midway. FRESNO CO.: Big Panoche Creek (Fresno-San Benito County line). KERN CO. LOS ANGELES CO.: Gorman (5 mi. S); Los Angeles; Santa Catalina Island. SAN DIEGO CO.: Escondido. SAN JOAQUIN CO.: Hospital Canyon; Tracy (6 mi. W). SANTA BARBARA CO.: Cachuma Canyon (2 mi. NW). SOLANO CO.: Dixon (8 and 9 mi. S); Putah Canyon. STANISLAUS CO.: Modesto. TULARE CO.: Visalia. YOLO CO.: Davis.

Floral Records. Andrena escondida should be considered as an oligolege of composites of the genus Layia. It has been collected from the plants listed below (including records in the literature).

Brassica sp., Calchortus catalinae, Encelia californica, Lasthena chrysostoma, Layia sp., L. chrysanthemoides, Plagiobothrys sp.

\section{Andrena (Hesperandrena) pulverea Viereck}

Andrena pulverea Viereck, 1917, Proc. Acad. Nat. Sci. Philadelphia, 68:569-570. Andrena (Hesperandrena) limnanthis Timberlake, 1951, Proc. United States Nat. Mus., 101:387-388. New synonymy.

The female of Andrena pulverea is like that of escondida in lacking pronotal humeral angles and lateral ridges but can be recognized by the large labral process which is entire, about one and one-half times as broad as it is long, usually triangular with a low apical boss. The male of pulverea is like that of escondida in having a black clypeus but can be separated from that species by the presence of weak humeral angles, flagellar segment 3 being slightly longer than segment 2 , rather than the inverse, and the lack of sternal subapical fimbriae.

FEMALE: Measurements and Ratios. $\mathrm{N}=20$; length, 9-10 mm; width, 2.0-2.5 $\mathrm{mm}$; WL, $\mathrm{M}=2.68 \pm 0.125 \mathrm{~mm} ; \mathrm{FL} / \mathrm{FW}, \mathrm{M}=0.94 \pm 0.005 ; \mathrm{FOVL} / \mathrm{FOVW}, \mathrm{M}=3.04 \pm 0.047$.

Integumental Color. Black except as follows: mandible with apical fifth to almost half rufescent; flagellum below dark brown; wing membranes hyaline, slightly infumate, yellowed, veins reddish brown to dark brown; metasomal terga with apical areas often slightly reddened, narrowly hyaline apically; tibial spurs yellow.

Structure. Antennal scape as long as first four flagellar segments or slightly shorter; flagellar segment 1 slightly longer than segments 2 plus 3, segments 2 and 3 subequal, shorter than 4, segments 5-7 about as long as broad. Eyes each almost four and a half times as long as broad, inner margins parallel. Mandibles short, apposite, with subapical tooth. Malar space short, linear. Galea as in escondida. Maxillary palpus as in escondida but segmental ratio about as 0.7:1.0:0.8:0.7:0.6:0.6. Labial palpus normal, segmental ratio about as 1.0:0.5:0.5:0.6. Labral process large, entire, usually triangular with blunted apex and small apical boss, occasionally rounded with apical boss; labrum apical to process as in escondida. Clypeus as in escondida but punctures sparse and indistinct almost to apical margin. Supraclypeal area and face above antennal fossae as in escondida. Facial fovea as 


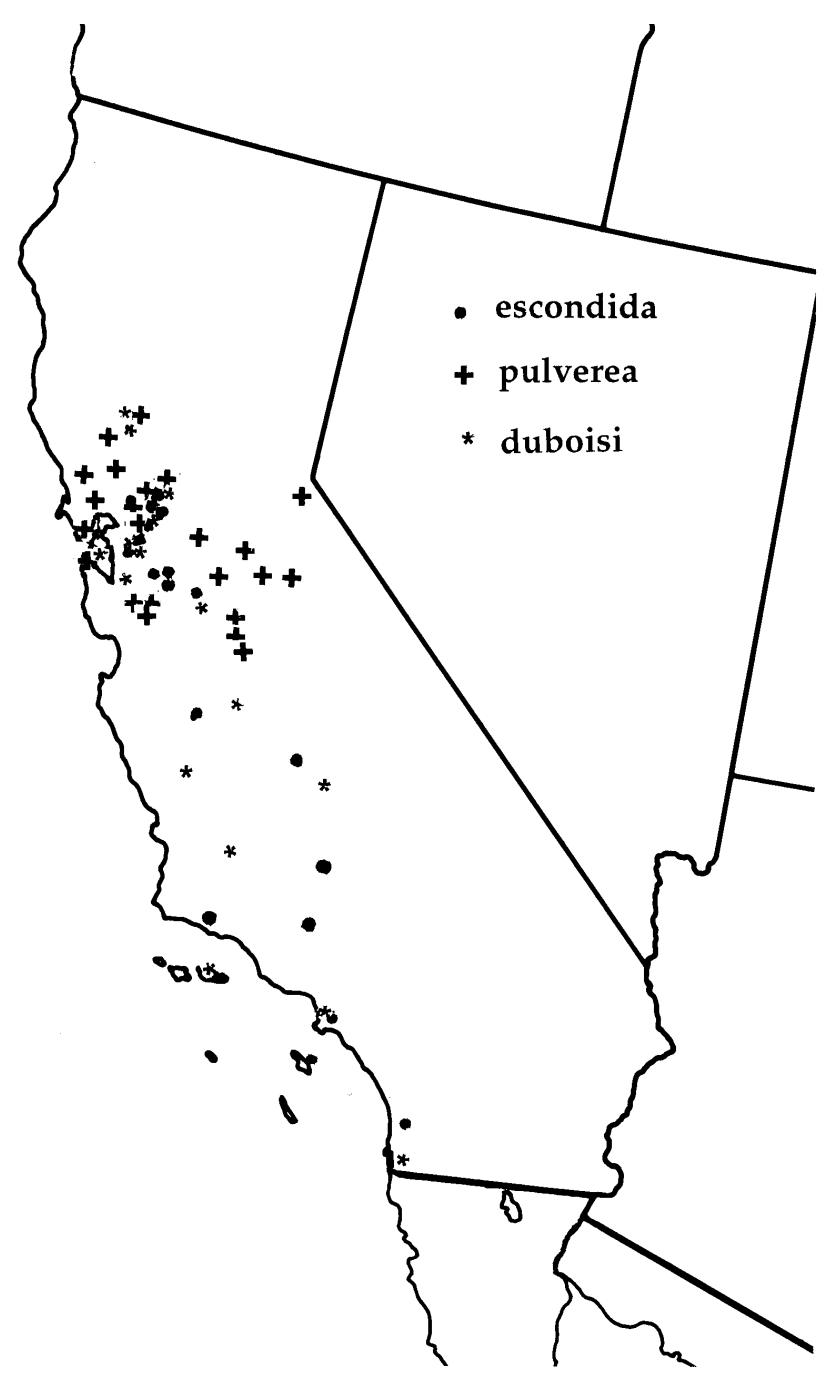

Fig. 1. Map showing the known distribution of A. pulverea, A. escondida, and A. duboisi.

in escondida but slightly longer. Vertex above lateral ocellus usually equals less than half an ocellar diameter. Genal area in profile as in escondida.

Pronotum as in escondida. Mesoscutum sculptured as in escondida but punctures sparse, obscure in anterior third and near parapsidal lines. Scutellum tessellate, punctures minute, widely separated. Propodeum as in escondida but dorsal enclosure not roughened basally. Pleurae as in escondida.

Metasomal terga sculptured as in escondida, punctures minute, essentially impunctate. Pygidial plate and sternal sculpturing as in escondida.

Vestiture. White to pale ochraceous except as follows: facial fovea with tomentum brown to golden brown, facial hairs otherwise often dark ochraceous; inner surfaces tarsi light yellow; scopal hairs often golden-brown along margin. Terga 2-4 with apical pale fasciae extremely weak, thin, that of tergum 2 interrupted medially by more than one-third width of tergum. Pollen-collecting hairs as in escondida but trochanteral flocculus usually with more abundant hairs.

MALE: Measurements and Ratios. $\mathrm{N}=20$; length, 7-9 mm; width, $1.5-2.5 \mathrm{~mm}$; $\mathrm{WL}, \mathrm{M}=2.41 \pm 0.123 \mathrm{~mm} ; \mathrm{FL} / \mathrm{FW}, \mathrm{M}=0.96 \pm 0.006 ; \mathrm{FS} 1 / \mathrm{FS} 2, \mathrm{M}=1.85 \pm 0.045$.

Integumental Color. As in female except as follows: wing membranes less infumate, veins often dark red; terga with apical areas translucent, ferruginous; sterna 2-5 narrowly hyaline apically. 
Structure. Antennae short, female-like; flagellar segment 1 usually slightly shorter than in escondida, twice as long as segment 2, segment 3 distinctly longer than 2, broader than long, segments 4-7 usually slightly longer than broad; scape length as in female. Mandibles apposite, short, with subapical tooth. Maxillary palpus and segmental ratio as in female. Labial palpus as in female but ratio about as 1.0:0.5:0.5:0.5. Labral process about twice as long as broad, at least as long as labrum apical to process, bidentate, recurved, shiny. Clypeus sculptured as in female but punctures more abundant, separated mostly by one to three diameters. Face above antennal fossae with minute rugulae often strongly diverging towards ocelli. Vertex as in female. Genal area at least one and onehalf times as broad as eye in profile, sculptured as in escondida. Pronotum with distinct humeral angles and weak lateral ridges. Thoracic sculpturing as in female. Metasomal terga sculptured as in female; sterna 2-5 tessellate, dull, with punctures mostly obscure. Terminalia (Figs. 22 and 23). Sternum 7 much as escondida but apical lobes slightly more separated; sternum 8 usually longer and narrower than in escondida.

Vestiture. White to pale ochraceous but inner surfaces of tarsi pale yellow and occasionally brown along inner margins of eyes and on vertex near ocelli. Metasomal terga 25 with apical pale fasciae extremely weak, that of tergum 2 interrupted medially by half width of tergum or more. Sterna 2-5 without dense subapical fimbriae of pale hairs.

Type Material. The holotype female of pulverea (PANS No. 4,043) was collected in California. The holotype female of limnanthis (USNM No 59,277) was collected at San Geronimo, Marin Co., California, April 23, 1913 by J.C. Bridwell.

Distribution. Andrena pulverea is known (Fig. 1) only from central California from Colusa County in the north to Merced County in the south. It has been collected from March 1 to June 2, but chiefly in late March and April. In addition to the types a total of 349 females and 93 males were examined from localities listed below (including records from the literature).

CALIFORNIA. CALAVERAS CO.: Angels Camp. COLUSA CO.: Bear Valley (9.7 mi. N of Highway 20). ELDORADO CO.: Alta. LAKE CO.: Middletown. MARIN CO.: Cypress Ridge; Fairfax; Olema (2 mi. S); Point Reyes; San Geronimo. MERCED CO.: Snelling (8 and 9 mi. NE). NAPA CO.: Pope Valley (and vicinity). SACRAMENTO CO.: Fair Oaks. SANTA CLARA CO.: Mt. Hamilton (5 mi. E); San Antonio Valley. SAN JOAQUIN CO.: Clements. SOLANO CO.: Dozier (11-12 mi. S of Dixon); Dixon (11 mi. S); Green Valley Estates. SONOMA CO.: Agua Caliente; Santa Rosa. STANISLAUS CO.: Evergreen Road (3.2 mi. W of Highway 120); La Grange (9 and 13 mi. NW). TUOLUMNE CO.: Chinese Camp; Mather (4-5 mi. S). YOLO CO.: Davis (and 5 mi. W).

Floral Records. Andrena pulverea is an oligolege of flowers of the genus Limnanthes and has been collected from flowers of the plants listed below.

Baeria sp., Blennospermum nannum, Limnanthes alba alba, L. douglasii, L. douglasii var. nivea, L. rosea, Montia perfoliata, Platystemon californicus, Ranunculus sp., Raphanus sativus.

\section{Andrena (Hesperandrena) duboisi Timberlake}

Andrena (Hesperandrena) duboisi Timberlake, 1951, Proc. United States Nat. Mus., 101:390-392.

Andrena duboisi is a small species marked by the lack of pronotal humeral angles and ridges, a metallic green integument (especially head and thorax), and galeae which are shiny and only extremely faintly shagreened. The male of $d u b o i s i$ can further be told from 
either A. escondida or A. pulverea by the yellow marking on the clypeus as described below and by sterna 2-5 having subapical fimbriae of extremely short, white plumose hairs.

FEMALE: Measurements and Ratios. $\mathrm{N}=20$; length, 6.5-7.5 mm; WL, $\mathrm{M}=$ $2.36 \pm 0.143 \mathrm{~mm} ; \mathrm{FL} / \mathrm{FW}, \mathrm{M}=0.79 \pm 0.007$; FOVL/FOVW, $\mathrm{M}=2.85 \pm 0.050$.

Integumental Color. Head and thorax metallic green except clypeus, scutellum, and metanotum often with violaceous reflections. Metasomal terga black with faint metallic green reflections; tergal apical areas hyaline apically to red or reddish brown basally; sterna without metallic reflections, apical areas more broadly hyaline. Wing membranes hyaline, yellow, veins red to reddish brown. Mandible with apical fifth to fourth rufescent; antennal flagellum brown below; tibial spurs light yellow.

Structure. Antennal scape as long as first four and one-third flagellar segments; flagellar segment 1 slightly longer than following two segments together; segment 2 about as long as 3 and shorter than 4; segments 5-7 about as long as broad. Eyes each three and two-thirds times as long as broad, inner margins parallel. Mandibles short, apposite, with subapical tooth. Malar space linear. Galea shaped as in escondida, surface shiny, faintly if at all shagreened. Maxillary palpus as in escondida but segmental ratio about as 0.8:1.0:0.8:0.7:0.5:0.7. Labial palpus as in escondida but ratio about as 1.0:0.5:0.5:0.7. Labral process short, two to three times as broad as long, weakly emarginate apically with rounded lateral angles; labrum apical to process about as long as process, moderately dulled by shagreening. Clypeus shaped as in escondida; dulled by fine tessellation and minute punctures separated mostly by about two puncture diameters except more crowded along apical margin. Supraclypeal area dulled by coarse tessellation. Face above antennal fossae with small parallel rugulae to ocelli. Facial fovea as in escondida. Vertex above lateral ocellus equals about half an ocellar diameter. Genal area in profile one and onehalf times width of eye or slightly less, surface dull, shagreened.

Pronotum without humeral angle or lateral ridge or with only a trace of these structures; surface dull, shagreened. Mesoscutum as in escondida but punctures separated by one to three puncture widths except slightly more crowded peripherally. Scutellum and metanotum similar. Propodeum as in escondida but finely punctatorugose, basal area extremely narrow. Pleurae as in escondida.

Metasoma sculptured as in escondida, virtually impunctate. Pygidial plate as in escondida but usually more pointed, V-shaped with apex rounded. Sterna as in escondida.

Vestiture. White to pale ochraceous except as follows: facial fovea with tomentum pale brown in upper three-fourths or more, pale at lower end only; hind tarsi with inner surface pale yellow; terga 2-4 with distinct apical pale hair bands, that on tergum 2 interrupted medially by less than one-third width of tergum, terga 3 and 4 with bands complete. Pollen-collecting hairs as in escondida.

MALE: Measurements and Ratios. $\mathrm{N}=9$; length, $6.0-7.0 \mathrm{~mm}$; width, 1.0-1.5 $\mathrm{mm}$; WL, $\mathrm{M}=1.68 \pm 0.169 \mathrm{~mm} ; \mathrm{FL} / \mathrm{FW}, \mathrm{M}=0.95 \pm 0.006$; FS1/FS2, $\mathrm{M}=2.10 \pm 0.087$.

Integumental Color. As in female except as follows: clypeus with mediobasal pale yellow macula covering half of clypeus or more; head and thorax with metallic reflections blue or bluish green, mesoscutum occasionally with slight violaceos reflections; metasomal terga with metallic bluish green reflections on basal half of each tergum, hyaline apical margins broader than in female; distitarsi usually red.

Structure. Antennae short, female-like; flagellar segment 1 as long as 2 plus 3, which are subequal and shorter than 4, segments 5-8 as long as broad or slightly longer; scape as in female. Eyes each slightly longer than three times as long as broad, diverging 
strongly towards vertex. Mandibles apposite, short, with subapical tooth. Galea as in female, shiny. Maxillary palpus as in female but segmental ratio about as 0.8:1.0:0.8:0.9:0.7:0.8. Labial palpus as in female but ratio about as 1.0:0.4:0.7:0.7. Labral process moderately long, about twice as broad as long, apical margin weakly emarginate, lateral teeth blunt, surface shiny; labrum apical to process about as long as process, dulled by shagreening. Clypeus sculptured as in female but minute punctures more abundant. Supraclypeal area as in female. Face above antennal fossae with parallel rugulae almost from inner eye margin to inner eye margin, in median third or less of facial area rugulae often diverge towards ocelli. Vertex short as in female. Pronotum with distinct humeral angles and complete lateral ridges, surface shagreened. Mesoscutum and scutellum sculptured much as in female. Propodeum as in female but surface outside of dorsal enclosure with punctures usually more distinct. Pleurae as in female.

Metasomal terga 1-6 sculptured as in female terga 1-5 but surfaces slightly shinier. Sterna much as in female. Sternum 7 has apical lobes broad and flattened, emargination much reduced. Sternum 8 with thick neck region, distinctly thicker than entire apical lobe.

Type Material. The female holotype (USNM No. 59, 279) of Andrena duboisi was collected at Davis, California, May 2, 1937 by J.J. DuBois.

Distribution. Andrena duboisi occurs in California (Fig. 1) from Colusa County in the north to San Diego County in the south. It has been collected from March 19 through May 12 and a total of 63 females and 9 males have been taken from localities listed below (including localities cited in the literature).

CALIFORNIA. ALAMEDA CO.: Niles. COLUSA CO.: Bear Valley $(9.7 \mathrm{mi} . \mathrm{N}$ of Highway 20 and $13.5 \mathrm{~km}$. N of Wilbur Springs). CONTRA COSTA CO.: Russelmann Park (Mt. Diablo); Walnut Creek. FRESNO CO.: Mendota. LOS ANGELES CO.: Los Angeles. MONTEREY CO.: Parkfield (6 mi. NE). SAN DIEGO CO.: San Diego. SAN FRANCISCO CO.: San Francisco. SAN LUIS OBISPO CO.: Simmler (15 mi. SE). SANTA BARBARA CO.: Christi Beach, Santa Cruz Island. SOLANO CO.: Dixon (9 mi. S); Dozier (11 mi. S of Dixon). STANISLAUS CO.: Turlock. TULARE CO.: Strathmore. YOLO CO.: Davis.

Floral Records. Andrena duboisi was collected at Davis by J.J. DuBois presumably at Baeria sp., according to Timberlake (1951). It has been collected from flowers listed below.

Baeria sp., B. chrysostoma, Blennosperma nannum, Centromadia pungens, Lasthenia chrysostoma, Layia chrysanthemoides, and Limnanthes douglasii.

\section{Andrena (Hesperandrena) lativentris Timberlake}

Andrena lativentris Timberlake, 1951, Proc. United States Nat. Mus., 101:388.

Andrena lativentris is a small species with pronotal humeral angles and lateral ridges in both sexes (although weak in the females) and black integument. The female can be recognized by the broad facial fovea separated from the lateral ocellus by about half an ocellar diameter or a little more and by the mesoscutal and scutellar hairs being mostly shorter than the width of the flagellum, although longer peripherally and especially in anterior fifth of the mesoscutum. The male of lativentris is marked by a yellow clypeal macula and sterna 2-5 with distinct subapical fimbriae of long, curled, relatively sparse, pale hairs.

FEMALE: Measurements and Ratios. $\mathrm{N}=20$; length, 8.0-9.5 mm; width, 2.0-

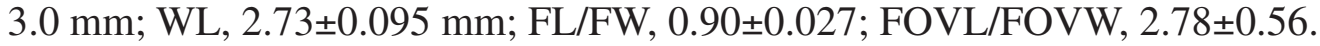

Integumental Color. Black except as follows: mandible with apical fourth rufescent; flagellum reddish brown below; wing membranes hyaline, not infumate, veins dark red or 
reddish brown; metasomal terga $2-4$ with apical areas broadly hyaline, colorless in apical fourth to third, reddened basally; tibial spurs pale yellow.

Structure. Antennal scape as long as first four flagellar segments or slightly more; flagellar segments as in escondida. Eyes each four times as long as broad, inner margins parallel. Mandibles short, apposite, with subapical tooth. Malar space short, linear. Galea as in escondida. Maxillary palpus as in escondida but segmental ratio about as 0.8:1.0:0.7:0.5:0.5:0.6. Labial palpus with ratio about as 1.0:0.5:0.4:0.4. Clypeus short, sculptured as in escondida but punctures extremely obscure. Supraclypeal area and face above antennal fossae sculptured as in escondida. Facial fovea extends below to just below a line at lower margins, antennal fossae two and one-fourth to two and one-third times as long as broad, separated from lateral ocellus by half an ocellar diameter or slightly more. Vertex above lateral ocellus short, equals about half an ocellar diameter or slightly more. Genal area in profile equals about one and one-third width of eye, surface dull, shagreened.

Pronotum without humeral angles and lateral ridges, surface dull, shagreened. Mesoscutum densely and finely tessellate, punctures minute, obscure, visible only at certain angles, separated by two or more puncture widths (slightly more crowded in anterior fifth and at extreme sides). Scutellum similar, not at all shiny. Propodeum declivous; dorsal enclosure tessellate, not at all punctatorugose; outside of enclosure with small sparse punctures; lateral carinae separated lateral from posterior surface complete. Pleurae dull, tessellate, punctures obscure, sculptured as in escondida.

Metasomal terga tessellate, dull, impunctate or punctures minute and obscure. Pygidial plate as in escondida. Sterna sculptured as in escondida.

Vestiture. White to pale ochraceous except as follows: facial fovea with tomentum silvery white to pale ochraceous, not brown in upper halves or more; metasomal terga 24 with white apical fasciae, that of tergum 2 narrowly interrupted medially; tergum 5 dark ochraceous medially. Pollen-collecting hairs as in escondida.

MALE: Measurements and Ratios. $\mathrm{N}=15$; length, 6.0-9.0 mm; width 2.0-3.0 $\mathrm{mm} ; \mathrm{WL}, \mathrm{M}=2.44 \pm 0.224 \mathrm{~mm} ; \mathrm{FL} / \mathrm{FW}, \mathrm{M}=0.94 \pm 0.014 ; \mathrm{FS} 1 / \mathrm{FS} 2, \mathrm{M}=1.92 \pm 0.085$.

Integumental Color. As in female except as follows: clypeus with large pale yellow maculae, dark laterally and apically; metasomal terga 2-5 with apical areas with at least apical halves hyaline, colorless; distitarsi rufescent.

Structure. Antennae short, female-like; flagellar segment 1 at least twice as long as segment 2, which equals segment 3, and broader than long; segments 4-7 about as long as broad; scape length as in female. Eyes three and one third times as long as broad, inner margins diverging towards vertex. Mandibles apposite, short, with subapical tooth. Galeae as in female. Maxillary palpus as in female but ratio about as 0.8:1.0:0.6:0.6:0.5:0.7. Labial palpus as in female but ratio about as 1.0:0.4:0.4:0.5. Labral process short, about twice as broad as long, emarginate, reflexed, shiny; labrum apical to process shorter than process. Clypeus dull, sculptured as in female. Supraclypeal area, face above antennal fossae and vertex as in female. Genal area as in female but only slightly broader than eye in profile.

Pronotum with weak humeral angles, lateral ridges present but weak, defined only above diagonal pronotal suture, dulled by fine shagreening. Thoracic sculpturing as in female but propodeum often finely punctatorugose at least basally; carina between lateral and posterior faces incomplete, short.

Metasomal terga sculptured as in female but surface slightly shiny, especially apical areas. Sternum 7 (Fig. 28) with lobes angulate laterally, apical imargination narrower. Sternum 8 (Fig. 29) with apical lobe entire, neck slightly broader than apical lobe, sternum thicker and broader than in pulverea. 
Vestiture. White except inner surfaces of tarsi pale yellow. Metasomal tera 2-5 with relatively weak apical fasciae, broadly interrupted medially on tergum 2 and narrowly on tergum 3. Sterna 2-5 with distinct pale subapical fimbriae of long, sparse, curled, white hairs (as in escondida but longer and sparser).

Type Material. The holotype female of lativentris (USNM No. 59,278) was collected from flowers of Baeria tenella at Strathmore, Tulare Co., California, May 29, 1937.

Distribution. Andrena lativentris has been collected in California (Fig. 2) from Colusa County south to San Diego County. It has been taken from March 9 through July 5, but chiefly from late March into May. A total of 24 females and 17 males were examined from localities listed below (including localities cited in the literature).

CALIFORNIA. COLUSA CO.: Bear Springs (S of Leesville). CONTRA COSTA CO.: Mt. Diablo; Russelman Park. KERN CO.: no locality. NAPA CO.: Butts Canyon (0.5 mi. S. of Napa Co. line). RIVERSIDE CO.: Elsinore; Hemet Lake, San Jacinto Mts.; Herkey Creek, San Jacinto Mts. SAN DIEGO CO.: Cuyamaca Lake. SOLANO CO.: Dixon (9 mi. S); Dozier (11 mi. S. of Dixon). TULARE CO.: Earlimart; Goshen (5.6 mi. $\mathrm{N})$; Strathmore. YOLO CO.: Davis.

Floral Records. Andrena lativentris is probably an oligolege of Baeria sp., but little is known concerning its floral preferences as yet. It has been collected from flowers of the following plants (records from the literature are included).

Baeria sp., B. gracilis, B. tenella, Blennospermum nannum, Lasthenia chryostoma, Layia chrysanthemoides, L. platyglossa.

\section{Andrena (Hesperandrena) baeriae Timberlake}

Andrena baeriae Timberlake, 1941, Bull. Southern California Acad. Sci., 39:194. Andrena (Hesperandrena) baeriae: Lanham, 1949, Univ. California Publ. Ent., 8:208.

Andrena baeriae differs from females of the preceding species by the distinct pronotal angles and lateral ridges. As in lativentris the integument is black (occasional slight metallic tints may be present on the frons) and the facial fovea is broad, being separated from the lateral ocellus by less than one ocellar diameter. The female is often marked with brown hairs posteromedially on the mesoscutum and medially on the scutellum, as well as on the face along the inner margins of the eyes. The male of baeriae has (Fig. 10) pronotal angles and ridges (the integument posterior to the lateral ridge is frequently less shagreened and moderately shiny) and has sterna 2-5 with weakly formed subapical fimbriae of long hairs as described below.

FEMALE: Measurements and Ratios. $\mathrm{N}=5$; length, 8.5-10.0 mm; width, 2.5$3.0 \mathrm{~mm} ; \mathrm{WL}, \mathrm{M}=2.72 \pm 0.159 \mathrm{~mm} ; \mathrm{FL} / \mathrm{FW}, \mathrm{M}=0.91 \pm 0.013 ; \mathrm{FOVL} / \mathrm{FOVW}, \mathrm{M}=$ $1.90 \pm 0.045 \mathrm{~mm}$.

Integumental Color. Integument black except as follows: frons above antennal fossae occasionally with slight metallic tints; mandibles with apical hyaline, veins red to reddish brown; metasomal terga narrowly hyaline apically, becoming dark towards base of apical area; tibial spurs pale yellow.

Structure. Antennal scape length about equal to first four flagellar segments; flagellar segment 1 as long as segments 2 plus 3, which are equal in length; segments 5-7 quadrate. Eyes each about four times as long as broad, inner margins parallel. Mandibles apposed, short, with subapical tooth. Malar space and galeae as in escondida. Maxillary palpus as in escondida but segmental ratio about as 0.8:1.0:0.7:0.6:0.5:0.6. Labial palpus as in escondida but ratio about as 1.0:0.5:0.6:0.6. Labrum as in escondida but usually gently emarginate apically. Clypeus, supraclypeal area and face above antennal fossae as 


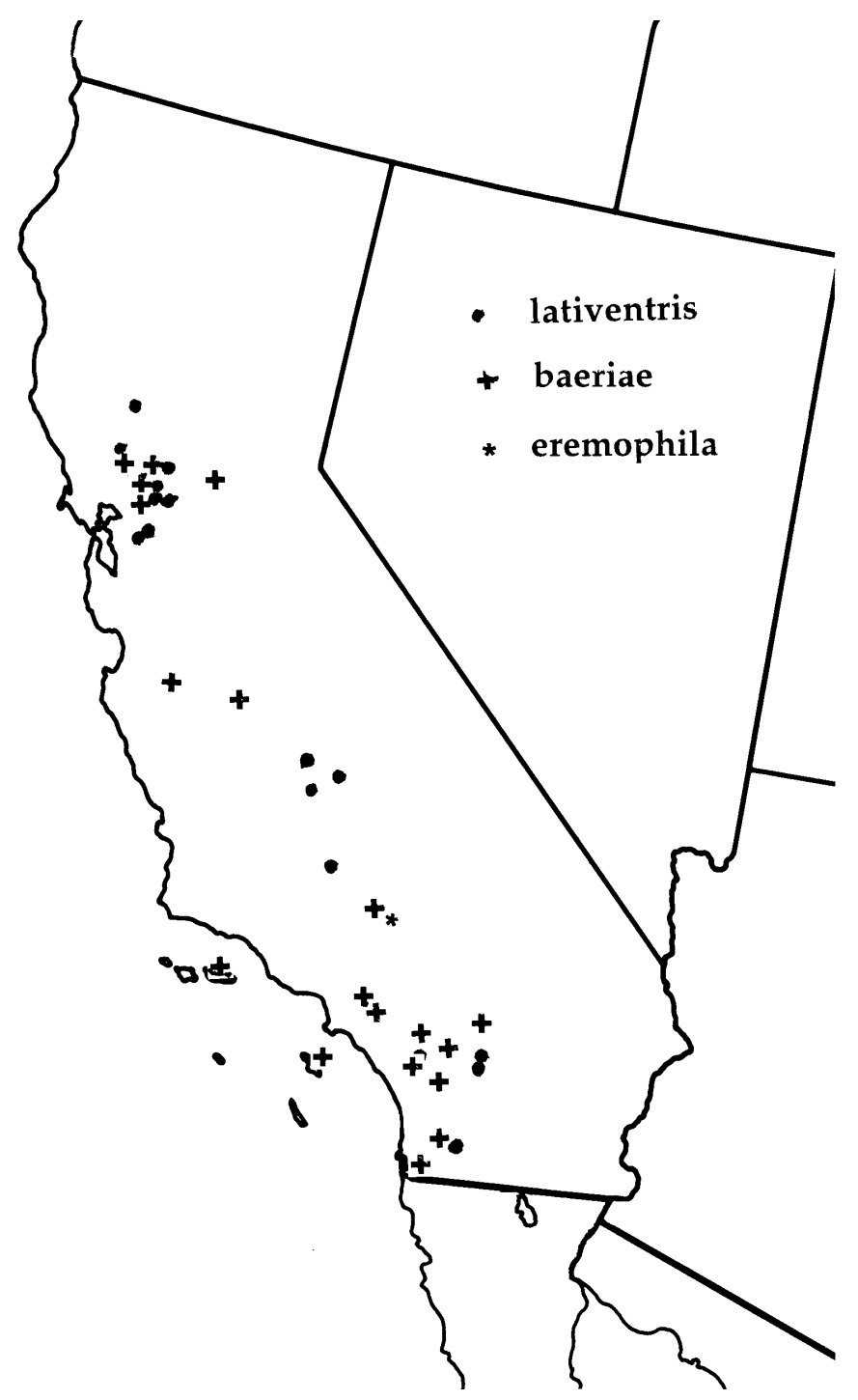

Fig. 2. Map showing the known distributions of A. lativentris, A. baeriae, and A. eremophila, n. sp.

in escondida. Facial fovea broad, separated from lateral ocellus by one ocellar diameter or somewhat more, extending below to well beyond a line across lower margins of antennal fossae. Genal area in profile almost one and one-half times as broad as eye, surface dull, shagreened.

Pronotum with humeral angles and lateral ridges (Fig. 10). Mesoscutum dull, tessellate, punctures sparse and obscure. Mesoscutum dull, tessellate, punctures sparse and obscure. Scutellum similar. Propodeum and pleurae as in escondida.

Metasomal terga sculptured as in escondida. Pygidial plate as in escondida, without raised rim in specimens at hand. Sterna 2-5 sculptured as in escondida.

Vestiture. White to pale ochraceous except as follows: along inner margins eyes and upper face dark ochraceous to brown; facial fovea with tomentum dark brown; mesoscutum and scutellum often with pale yellow hairs; apices of femora and tibial plates occasionally with brown hairs; terga 5 and 6 with brown hairs at least medially; tarsi with inner surfaces with pale yellow hairs. Mesoscutum and scutellum with hairs mostly longer than width of flagellum, relatively sparse; metasomal tergum 2 with apical pale fascia interrupted medially. Pollen collecting hairs as in escondida.

MALE: Measurements and Ratios. $\mathrm{N}=11$; length 6-8 mm; width, 1.5-2.0 mm; $\mathrm{WL}, \mathrm{M}=2.27 \pm 0.370 \mathrm{~mm}$; FL/FW, $\mathrm{M}=0.95 \pm 0.026$; FSl/FS2, 2.24 \pm 0.026 . 
Integumental Color. As in female except as follows: terga 2-5 with apical areas more broadly hyaline apically, often half of apical area colorless; tergum 2 laterally usually with small, subapical, yellow spot surrounded by rufescent border, terga 1 and 3 rarely with similar spots but usually rufescent or reddish brown and without yellow.

Structure. Antennae short, female-like; flagellar segment 1 twice as long as segment 2, which is about as long as segment 3 and broader than long; segments 4-7 about as long as broad; scape length as in female. Eyes each about three and one-half times as long as broad or slightly longer, inner margins diverging towards vertex. Mandibles slightly decussate, short, with subapical tooth. Galeae as in female. Maxillary palpus as in female but ratio about as 0.8:1.0:0.8:0.5:0.5:0.6. Labial palpus as in female but ratio about as 1.0:0.5:0.4:0.5. Labral process and labrum as in escondida. Clypeus sculptured as in female but punctures slightly denser, separated largely by one to two puncture widths or less. Supraclypeal area as in female. Face above antennal fossae with rugulae as in female but diverging upward immediately below ocelli. Vertex and genal area as in female.

Pronotum with distinct humeral angles and lateral ridges, surface dulled by shagreening anterior to lateral ridge and shiny to moderately shiny posterior to ridge. Thoracic sculpturing as in female.

Metasomal sculpturing as in female but terga 1-5 slightly shinier. Sterna as in female. Sterna 7 and 8 small, sternum 7 (Figs. 13, 28) with emargination relatively deep and narrow, sides angulate near the apical margin; sternum 8 (Fig. 29) much as in lativentris but much smaller and narrower.

Vestiture. White to pale ochraceous but inner surfaces of tarsi pale yellow. Metasomal terga 2-5 with weak apical pale fasciae, those on terga 2 and 3 interrupted medially often by one-third width of tergum or more. Sterna 2-5 with distinct subapical fimbriae of long, curled, sparse hairs, individually each separated by two or more hair-widths so that distinct dense white bands not formed (as in lativentris).

Type Material. The holotype female (CAS No. 14,349) of baeriae was collected from flowers of Baeria chrysostoma var. gracilis and B. aristata at Riverside, California, from March 29 to April 6 by P.H. Timberlake.

Distribution. Andrena baeriae is known (Fig. 2) from San Diego County north to Yolo County, California. It has been collected from March 3 to July 5, but chiefly in late March into May. A total of 94 females and 16 males from the localities listed below (including records from the literature) were examined. La Mesa, San Diego County listed below is the probable locality for a single male labelled as from La Mesa, in Baja California, Mexico. However, the authors cannot find such a locality in Baja California. LaMesa in San Diego County, California, on the other hand, lies about 3 miles east of the San Miguel Mission in San Diego County which is mentioned on the original label and also not far from San Miguel Mountain. We conclude that an error was made on the hand-written label by the collector (T.D.A. Cockerell).

CALIFORNIA. KERN CO.: Rosamond (hills N of). FRESNO CO.: Mendota. LOS ANGELES CO.: Puente Hills; Santa Catalina Island; Whittier. NAPA CO.: Aetna springs (N. of Butts Canyon). RIVERSIDE CO.: Gavilan; Lake Perris; Riverside; Sta. Rosa Plateau Reserve (WSW of Murrieta). SACRAMENTO CO.: Folsom. SAN BENITO CO.: Hollister (35 mi. S). SAN BERNARDINO CO.: Morongo Valley. SAN DIEGO CO.: Lake Cuyamaca; La Mesa (3 mi. E of San Miguel Mission). SANTA BARBARA CO.: Christi Beach, Sta. Cruz Island. SOLANO CO.: Dixon (9 and 11 mi. S). YOLO CO.: Davis.

Floral Records. Andrena baeriae is probably an oligolege of flowers of the genus Baeria but little is actually known of its pollen preferences. It has been collected from 
flowers of the plants listed below (including records from the literature).

Baeria sp., B. aristata, B. chrysostoma var. gracilis, Layia sp., L. chrysanthemoides.

\section{Andrena (Hesperandrena) leucomystax, new species}

Andrena leucomystax is a small species with distinct pronotal angles and lateral ridges in both sexes. It differs from lativentris in both sexes by having distinctly metallic green integument on the face and mesoscutum, by having the scutellum and often the posteromedial area of the mesoscutum shiny with shagreening slight or absent. The female has metasomal terga 2 and 3 with apical pale fasciae that are much as in escondida or baeriae. The male has a dense beard of long white hairs on the mostly pale yellow clypeus and sterna 2-5 short white subapical fimbriae narrowly interrupted medially (usually by less than one-third width of tergum).

FEMALE: Measurements and Ratios. $\mathrm{N}=20$; length, $7.0-8.5 \mathrm{~mm}$; width, 2.0-3.0 $\mathrm{mm}$; wing length, $\mathrm{M}=2.41 \pm 0.150 \mathrm{~mm}$; FL/FW, $\mathrm{M}=0.86 \pm 0.006$; FOVL/ FOVW, $\mathrm{M}=$ $2.99 \pm 0.077$.

Integumental Color. Black except as follows: frons above antennal fossae with greenish metallic tints; mandible with apical third to half rufescent; flagellar segments 3-10 dark red below, segments 1 and 2 dark brown; mesoscutum with anterior third with metallic green tints; wing membranes hyaline, yellowed, veins red to reddish brown; metasomal terga hyaline apically, becoming dark towards base of apical area, usually without metallic tints basally; tibial spurs testaceous.

Structure. Antennal scape as in baeriae. Eyes as in baeriae but diverging slightly towards vertex. Mandibles and malar space as in escondida. Face sculptured much as in escondida and baeriae. Galeae as in escondida except surface shiny, not at all tessellate or shagreened. Maxillary palpus short as in baeriae, segmental ratio about as 1.0:0.8:0.6:0.5:0.3:0.4. Labrum as in baeriae, with process short, broad, gently emarginate apicomedially. Clypeus, supraclypeal area and face above antennal fossae as in escondida but face above antennal fossae with longitudinal rugulae relatively coarse. Facial fovea relatively short and narrow, separated from lateral ocellus by one ocellar diameter or slightly more. Vertex above lateral ocellus equal to half an ocellar diameter. Genal area as in baeriae.

Pronotum with humeral angles and lateral ridges well formed, space posterior to lateral ridge relatively shiny. Mesoscutum usually shiny and without shagreening posteromedially, otherwise as in baeriae. Scutellum usually without shagreening, shiny, with punctures scattered peripherally (Fig. 19). Propodeum and pleurae as in escondida.

Metasomal terga sculptured much as in escondida or baeriae but tergum 1 not densely tessellate, rather coarsely shagreened, and terga 2-4 with basal areas usually moderately shiny, shagreened but not densely so. Sterna 2-5 sculptured much as in escondida.

Vestiture. White to pale ochraceous except as follows: facial fovea with tomentum pale brown to dark ochraceous; vertex and thoracic dorsum with hairs ochraceous to yellow; terga 2-4 with white apical fasciae, those on terga 2 and 3 narrowly interrupted medially usually by distinctly less than one-third width of tergum; terga 5 and 6 with vestiture white. Pollen collecting hairs as in escondida (Figs. 16 to 18).

MALE: Measurements and Ratios. $\mathrm{N}=20$; length, $6.0-8.0 \mathrm{~mm}$; width $1.2-2.0$ $\mathrm{mm}$; wing length, $\mathrm{M}=2.26 \pm 0.190 \mathrm{~mm} ; \mathrm{FL} / \mathrm{FW}, \mathrm{M}=0.93 \pm 0.007 ; \mathrm{FS} 1 / \mathrm{FS} 2, \mathrm{M}=2.09 \pm 0.034$.

Integumental Color. As in female except as follows: clypeus pale yellow except narrow infuscation along posterior border and in lateral angles and dark apical border; 
terga 1-3 basal areas without lateral pale spots; face above antennal fossae and anterior third of mesoscutum with metallic green reflections.

Structure. Antennae short, female-like; flagellar segment 1 as long as segments 2 and 3 together or slightly longer; segment 2 subequal in length to segment 3 ; segments 4 6 about as long as broad, remaining segments distinctly longer. Eyes, mandible, and genal area as in baeriae. Galea as in female, surface shiny, unshagreened. Maxillary palpus as in female, ratio about as 1.0:1.0:0.8:0.6:0.4:0.8. Labial palpus as in female but segmental ratio about as 1.0:0.6:0.7:0.6. Labral process somewhat recurved, distinctly toothed. Clypeus sculptured as in female, but punctures not evident due to pale color. Supraclypeal area and face above antennal fossae sculptured as in female. Vertex and genal area as in female.

Pronotum with distinct humeral angles and lateral ridges, surface anterior to ridge tessellate, dull, posterior to ridge moderately shiny. Mesoscutum usually with small posteromedian area shiny, unshagreened; scutellum usually shiny, unshagreened or relatively faintly so.

Metasomal sculpturing as in female but terga 2-5 usually slightly shinier. Sterna as in female. Sternum 7 (Fig. 30) similar to that of duboisi (Fig. 24) but apical lobes broader and slightly slanted from the apex, median emargination slightly deeper; sternum 8 (Fig. 31) with apical lobe entire, neck region much broadened posteriorly as in duboisi (Fig. 25).

Vestiture. White to pale ochraceous but inner surfaces of tarsi pale yellow. Metasomal terga 2-5 with white apical fasciae usually interrupted medially on terga $2-4$ as in baeriae. Sterna 2-5 with weak subapical fimbriae of extremely short, white, plumose hairs (as in duboisi).

Type Material. The holotype female and allotype male with one female paratype of leucomystax were reared from a nest site located at 9 miles S of Dixon, Solano County, California, October 18, 1968 by B.J. Donovan. The holotype and allotype are deposited in the collection of the California Academy of Sciences.

Distribution. Andrena leucomystax is known (Fig. 3) only from California. In addition to the type series associated with the holotype, 27 female and 24 male paratypes (CAS, UCD, UCR, LACM, USU, INHS) from California were collected as follows:

CALIFORNIA. FRESNO CO.: Coalinga (14.5 mi. N). - 1 female, Mar. 21, 1963, J.W. MacSwain. Mendota._ 4 females, March 22, 1967, R.R. Snelling; 2 males, March 14, 1957 from Baeria sp., R.R. Snelling. SAN LUIS OBISPO CO.: Simmler (15 mi. SE at south end of Soda Lake)._- 1 male, March 2, 1969, H.B. Leach. SOLANO CO.: Dixon (9 mi. S)._ 2 males on Layia chrysanthemoides, April 17, 1969, R.W. Thorp; 2 males, April 11, 1975, R.B. Kimsey; 1 male, April 24, 1969, R.W. Thorp; 2 females, April 27, 1949, W.F. Chamberlain on L. chrysanthemoides. Dozier (11 mi. S of Dixon). - 1 female on Blennospermum nanum Mar. 26, 1969, R.W. Thorp; 1 female, 1 male on Limnanthes douglasii, Mar 26, 1969, B.J. Donovan; 1 female on Lasthenia chrysostoma, April 3, 1969, B.J. Donovan; 1 female on B. nanum, Apr. 3, 1969, D.L. Briggs; 1 female, 2 males on $B$. nanum, March 19, 1969, R.W. Thorp; 3 females on L. chrysostoma, Apr. 17, 1969, R.W. Thorp; 5 females on L. chrysostoma, May 1, 1969, D.L. Briggs; 1 male on B. nannum, March 8, 1969, B.J. Donovan; 1 male, April 3, 1971, R.W. Thorp; 2 males on B. nannum, March 26, 1969, B.J. Donovan; 1 male on B. nannum, April 11, 1969, B.J. Donovan; 2 males on L. chrysostoma, April 3, 1969, B. J. Donovan; 2 males, April 3,1969, J. Marsh; 1 male at nest, May 1, 1969, R.W. Thorp; 1 female on B. nannum, March 19, 1969, B.J. Donovan; 2 males on Downingia pulchella, April 24, 1969, R.W. Thorp; 1 female on $L$. lasthenia, May 1, 1969, R.W. Thorp; 1 male at nest site, April 3, 1969, B.J. Donovan; 1 female at nest site, May 1, 1969, B.J. Donovan. STANISLAUS CO.: LaGrange.- 1 female on Baeria sp., April 26, 1952, R. Snelling. TULARE CO.: Strathmore.-1 female on 
Baeria tenella, March 28, 1937, P.H. Timberlake. YOLO CO.: Davis. - 1 female, May 12, 1937, J.J. DuBois. Winters. - 1 female on Baeria sp., March 6, 1947, G.E. Bohart.

\section{Andrena (Hesperandrena) dissona, new species}

Andrena dissona is a small bee which has a distinct pronotal humeral angle and lateral ridge in both sexes. The female can be distinguished from that of other species with distinct pronotal angle and ridge by having a black, moderately shiny to shiny mesoscutum and scutellum, the apical fascia of tergum 2 usually broadly interrupted medially and has the mesoscutal punctures (especially just inside of parapsidal lines) more distinct and more crowded. The male has a partly yellow clypeus and sterna 2-5 with subapical fimbriae of long, down-curved, weakly plumose, relatively sparse hairs.

FEMALE: Measurements and Ratios. $\mathrm{N}=5$; length, 7.0-7.5 mm; width, 2.25$2.50 \mathrm{~mm}$; wing length, $2.44 \pm 0.287 \mathrm{~mm}$; FL/FW, $\mathrm{M}=0.85 \pm 0.011$; FOVL/FOVW, $\mathrm{M}=$ $2.63 \pm 0.16$.

Integumental Color. Black except as follows: metallic tints occasionally present on face above antennal fossae but absent on mesonotum and mesepisternum; metasomal terga with apical areas entirely or largely hyaline, clear to yellowish; terga 1 and 2 with basal areas with small, apical, brownish yellow, apicolateral spots, with a narrow yellowish line connecting spots across tergum; sterna with apical areas hyaline; wing membranes hyaline, veins reddish brown.

Structure. Antennal scape equal to or slightly less than first four flagellar segments; flagellar segments as in baeriae but segments 5-9 about as long as broad or slightly longer, segment 10 distinctly longer than broad. Mandibles, malar space and galeae as in baeriae but galeae shinier, shagreening delicate (not as shiny as in perdissona). Labrum short and broad as in baeriae but usually not emarginate apicomedially. Maxillary palpus as in escondida but segmental ratio about as 1.0:1.0:0.8:0.6:0.4:0.7. Labial plapus as in escondida but ratio about as 1.0:0.6:0.4:0.7. Clypeus, supraclypeal area and face above antennal fossae as in escondida but clypeal punctures somewhat more abundant in apical half and more distinct. Facial fovea and genal area as in baeriae. Vertex above lateral ocellus equals about half an ocellar diameter.

Pronotum with distinct humeral angles and lateral ridges. Mesoscutum moderately shiny, shagreening coarse; punctures moderately well formed, in area just mesad of parapsidal line mostly separated by one puncture width or slightly less. Scutellum similar but occasionally shagreening less distinct, moderately shiny. Propodeum and pleurae as in escondida.

Metasomal terga scultpured as in escondida. Pygidial plate as in escondida, with broad raised rim especially in apical two-thirds. Sterna 2-5 as in escondida.

MALE: Measurements and Ratios. $\mathrm{N}=15$; length, 6.5-7.0 mm; width, 2.0-2.5 $\mathrm{mm}$; wing length, $\mathrm{M}=2.23 \pm 0.128 \mathrm{~mm} ; \mathrm{FL} / \mathrm{FW}, \mathrm{M}=0.86 \pm 0.007 ; \mathrm{FS} 1 / \mathrm{FS} 2, \mathrm{M}=2.13 \pm$ 0.065 .

Integumental Color. Black except as follows: clypeus with cream-colored or pale yellow mediobasal macula, apical third or fourth and lateral angles of clypeus black; face above antennal fossae and mesepisterna often with faint metallic reflections; flagellum below dark reddish brown; wing membranes hyaline, clear, veins reddish brown; metasomal terga and sterna with apical areas hyaline, colorless to slightly yellowed basally.

Structure. Antennae short, female-like; flagellar segment 1 longer than segments 2 plus 3, segment 2 subequal in length to 3 which is slightly shorter than 4, segments 5-10 about as long as broad, 11 distinctly longer than broad. Eyes each about one and one-half 


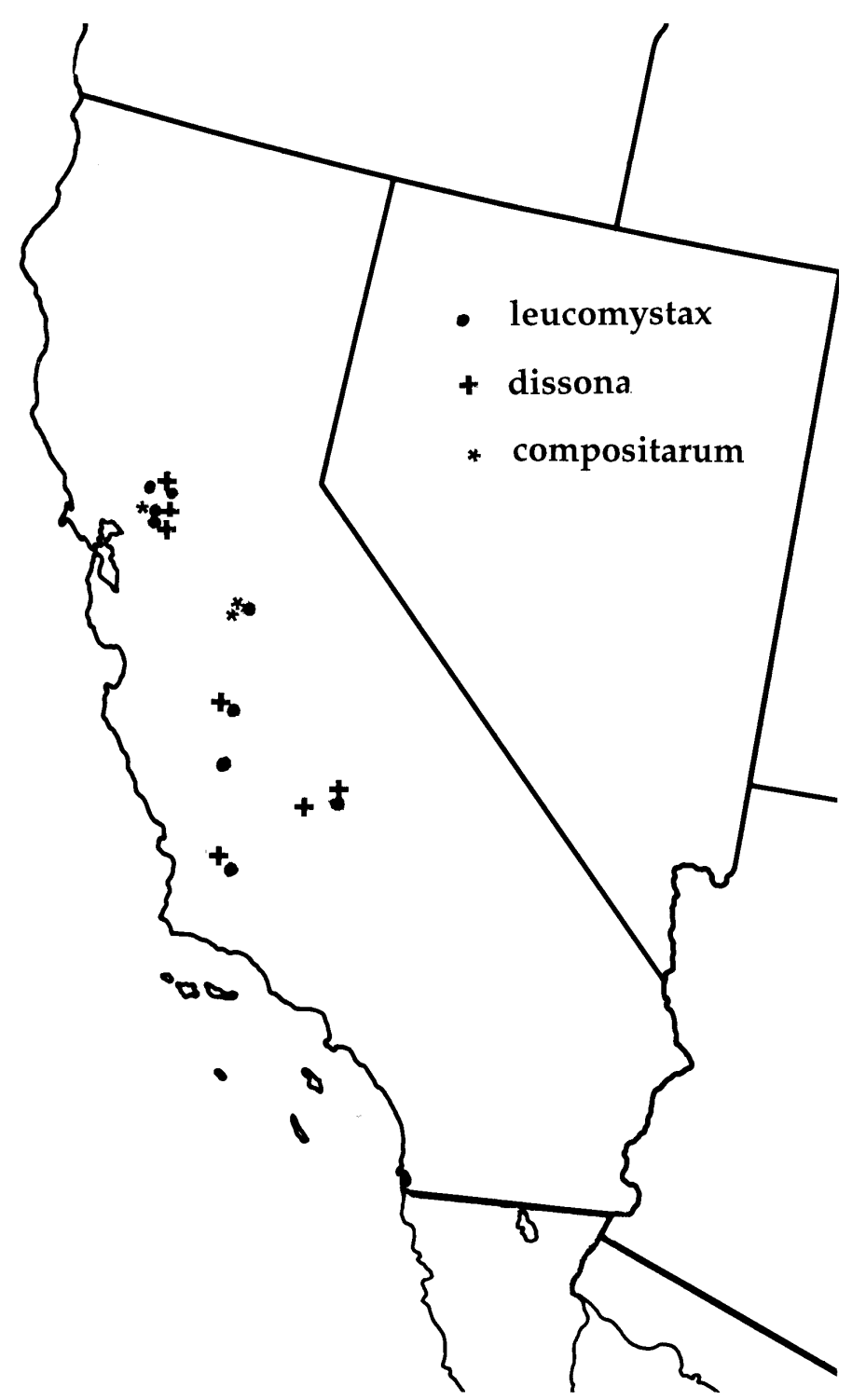

Fig. 3. Map showing the known distributions of A. leucomystax, n. sp.; A. dissona, n. sp.; and A. compositarum, n. sp.

times as long as broad, inner margins diverge towards vertex. Mandibles and galeae as in baeriae. Maxillary palpus as in female but segmental ratio about as 1.0:1 .0:0.7:0.6:0.4:0.7. Labial palpus as in baeriae but ratio about as 1.0:0.3:0.2:0.3. Labral process and labrum as in escondida but not at all or only slightly emarginate apicomedially. Clypeus as in baeriae but punctures hardly visible. Supraclypeal area and face above antennae as in beariae. Vertex above lateral ocellus equals about half an ocellar diameter.

Pronotum with distinct humeral angles and lateral ridges much as in baeriae. Thoracic sculpturing as in female but scutellum occasionally moderately shiny, shagreened.

Metasomal sculpturing as in female but terga 3-5 moderately shiny. Sterna as in female. Sternum 7 (Fig. 32) with apical lobes narrow, sides not strongly angulate, emargination deep and narrow; sternum 8 (Fig. 33) much as in lativentris but much smaller.

Vestiture. White to pale ochraceous but on inner surfaces of tarsi yellow and on dorsum of thorax often slightly darker ochraceous. Metasomal terga 2-5 with weak apical pale fasciae, those on terga 2 and 3 interrupted medially, usually by more than a third of width of tergum. Sterna 2-5 with subapical fimbriae of relatively sparse, long, curved downward, plumose hairs. 
Type Material. The holotype female of dissona (CAS) was collected at Strathmore, Tulare Co., California, from flowers of Baeria chrysostoma, March 29, 1937 by P.H. Timberlake. The allotype male of dissona (CAS) was collected at Earlimart, Tulare County from flowers of Baeria terrella, March 9, 1937 by P.H. Timberlake. Four female and fifteen male paratypes from California (Fig. 3) (UCB, UCD, INHS, CAS, LACM) are as follows:

CALIFORNIA. SOLANO CO.: Dixon (9 mi. S).— 1 male, April 24, 1969 from Layia chrysanthemoides or Baeria chrysostoma, B.J. Donovan; 1 male, April 24, 1969 from L. chrsanthemoides or B. chrysostoma, R.W. Thorp; 1 male April 17, 1969 from L. chrysanthemoides, R.W. Thorp; 1 male April 17, 1969, from L. chrysanthemoides D.L. Briggs. Dixon (11 miles S at Dozier)._- I male April 17, 1969, from Layia chrysanthemoides, D.L. Briggs. YOLO CO.: Davis. - 1 male, May 12, 1937, M. DuBois.

\section{Andrena (Hesperandrena) eremophila, new species}

This modest-sized species is known only from specimens of the female sex all collected at one locality. Like the females of A. escondida, these females do not have pronotal angles nor pronotal dorsolateral ridges, nor do they have metallic reflections in the dark color. They differ from females of escondida by having a larger, coarsely rugulose apical clypeal area and by having the metasomal terga (especially the first three) shinier due to the more fragile and less dense shagreening.

FEMALE: Measurements and Ratios. $\mathrm{N}=5$; length, $8-9 \mathrm{~mm}$; width, about $3 \mathrm{~mm}$; wing length, $2.41 \pm 0.093 \mathrm{~mm} ; \mathrm{FL} / \mathrm{FW}, \mathrm{M}=0.93 \pm 0.007 ; \mathrm{FOVL} / \mathrm{FOVW}, \mathrm{M}=3.20 \pm$ 0.273 .

Integumental Color. Black except as follows: mandible with apical third to half rufescent; flagella slightly reddened below; wing membrane hyaline, veins brown to reddish brown; metasomal terga with apical areas half or more hyaline, basal areas often with rufescent areas present apically; tibial spurs yellow.

Structure. Scape as long as first four flagellar segments or slightly more; flagellar segment 1 longer than segments 2 plus 3 which are about equal in length and broader than long; segments 4-8 as broad as long or slightly longer. Eyes, mandibles, and malar space as in escondida. Galea pointed, outer margin apical half gently concave; surface moderately shiny, tessellation extremely fine. Maxillary palpus exceeds galea by last two segments, segmental ratio about as 1.0:1.4:0.5:0.4:0.4:0.5. Labial palpus normal, segmental ratio about as 0.8:1.2:0.3:0.4. Labral process about three times as broad as long, shallowly emarginate medially, labrum apical to process slightly shorter, shallowly, transversely grooved, moderately shiny. Clypeus gently rounded from side to side, surface in basal half or slightly more dull, tessellate with relatively sparse, small punctures; apical third to half moderately shiny, coarsely reticulorugose. Supraclypeal area, face, and facial foveae much as in escondida.

Pronotum without humeral angle or dorsolateral ridges, surface dull, shagreened. Mesoscutum and scutellum as in escondida. Propodeum and pleurae as in escondida. Metasomal terga sculptured as in escondida. Pygidial plate and sterna as in escondida.

Vestiture. Essentially as described for the female of escondida.

Type Material. The female holotype of eremophila (USU) and the three female paratypes were collected at Mojave, Kern County, California, April 10, 1936 by G.E. and R.M. Bohart (Fig. 2). One female paratype was collected at the same locality April 11, 1938 by G.E. and R.M. Bohart. Paratypes will be deposited at the following institutions: USU, OSU (Oregon State Univeristy), CAS, INHS. 


\section{Andrena (Hesperandrena) compositarum, new species}

Andrena compositarum is a relatively small species similar to A. escondida. However, the female of compositarum has the pronotum with complete pronotal angles and dorsoventral ridges, although these may be weak. The female of compositarum can be distinguished by the facial foveae being covered with brown to dark brown hairs and the dorsum of the thorax having at least some brown hairs. The male of compositarum can be separated from that of escondida by having a black clypeus, weak but distinct pronotal angles and dorsolateral ridges, and sterna 2-5 with subapical fimbriae consisting of very long, curved hairs, longer than in escondida males but not as dense nor as white.

FEMALE: Measurements and Ratios. $\mathrm{N}=6$; length, 9-9.5 mm; width, 2.0-2.5 $\mathrm{mm} ; \mathrm{WL}, \mathrm{M}=2.69 \pm 0.080 \mathrm{~mm} ; \mathrm{FL} / \mathrm{FW}, \mathrm{M}=0.891 \pm 0.008 ; \mathrm{FOVL} / \mathrm{FOVW}, \mathrm{M}=2.34 \pm$ 0.061 .

Integumental Color. As in escondida in all particulars.

Structure. Antennal scape as long as first four flagellar segments or almost so; flagellar segment 1 as long as following three segments or slightly shorter, segments 2 and 3 shorter than broad, of equal length, and slightly shorter than segment 4; segments 5 to 7 or 8 about as long as broad. Eyes, mandibles as in escondida; malar space surpassing tip of galea to slightly shorter; segmental ratio about as 0.5:0.7:0.5:0.5:0.4:0.5. Labial palpus normal, segmental ratio about as 0.9:0.4:0.4:0.5. Labral process short, distinctly but shallowly emarginate; labrum apical to process flat to rounded, dull, often base (near process) with weak, short, longitudinal rugulae, finely tessellate. Clypeus, supraclypeal area and face sculptured as in escondida. Facial fovea extends to distinctly below lower margins of antennal fossae. Genal area (head in profile) more than twice as broad as eye, sculptured as in escondida.

Pronotum with humeral angles and dorsolateral ridges, but relatively weak. Mesoscutum and scutellum with small distinct punctures separated by one to two or three puncture widths, dulled by distinct tessellation. Scutellum as in escondida but basal area not reticulorugose, slightly roughened more than the general tessellation. Mesopleurae dull, tessellate, with scattered small but distinct punctures separated by two to four or more puncture widths.

Metasomal terga sculptured as in escondida; pygidial plate as in escondida but not as distinctly U-shaped, more V-shaped with rounded apex. Sterna sculptured as in escondida.

Vestiture. Pale ochraceous to ochraceous except as follows: facial foveae with short brown tomentum, paler on lower third or less; mesoscutum and scutellum with some brown hairs medially, usually largely brown; scopal hairs along posterior margin of tibia and basitarsis usually pale brown to brown. In other respects vestiture as escondida.

MALE: Measurements and Ratios. $\mathrm{N}=11$; length, $8-9 \mathrm{~mm}$; $\mathrm{WL}, \mathrm{M}=2.60 \pm$ $0.086 \mathrm{~mm} ; \mathrm{FL} / \mathrm{FW}, \mathrm{M}=0.94 \pm 0.010 ; \mathrm{FS} 1 / \mathrm{FS} 2, \mathrm{M}=2.35 \pm 0.081$.

Structure. Antennae as in escondida but flagellar segment 2 equal to or slightly shorter (allotype) than segment 3. Eyes each about three and a half times as long as broad, inner margins diverging strongly towards vertex. Mandibles and galeae as in escondida. Maxillary palpus short, exceeding galea by no more than last maxillary palpal segment, segmental ratio about as 7.0:7.0:4.5:4.0:3.5:3.5. Labial palpus with segmental ratio as 9.0:4.0:3.0:4.0. Labral process deeply emarginate apically, lateral teeth curved down, sharp; labrum apical to process (measured from tips of apical teeth) distinctly shorter than process, shiny. Clypeus, supraclypeal area, face and vertex above ocelli as in female. Genal area broad, in profile, one and one-half times as wide as width of eye or slightly longer. Pronotum with distinct lateral angles but dorso-ventral ridge weak, especially in 
lower half, sculpture of thorax as in female. Metasomal terga sculptured much as in female but shagreening weaker and surfaces shinier, especially on terga 3-6.

Sternal sculpturing as in female. Sternum 7 with apical lobes rounded, emargination narrow, moderately deep. Sternum 8 with apical lobe short, shallowly emarginate medially, neck region almost parallel-sided, slightly broader than apical lobe.

Vestiture. Generally white to pale ochraceous, not brown on face or thoracic dorsum as in female. Terga 2-5 with distinct subapical fimbriae consisting of long, relatively sparse hairs (especially laterally) which curve downward, unlike the dense white bands of straight shorter hairs of escondida.

Type Material. The holotype female (UCD), allotype male (UCD), one female and one male paratype (INHS) of compositarum were collected from Layia chrysanthemoides at Dixon (9 miles S), Solano Co., California, by R.W. Thorp on April 17, 1969. The holotype and allotype are deposited in the California Academy of Natural Sciences. Paratypes are in the collections of the University of California at Davis and the Illinois Natural History Survey in Champaign. Four female and nine male paratypes were collected from California (Fig. 3) as follows:

SOLANO CO.: Dixon (9 mi. S). 1 female, May 8, 1969 from Layia chrysanthemoides, R.W. Thorp; 1 female, May 1, 1969, from L. chrysanthemoides, B.J. Donovan; 1 female, 1 male, April 24, 1969 from L. chrysanthemoides, R.W. Thorp; 2 males from $L$. chrysanthemoides, April 24, 1969, B.J. Donovan. STANISLAUS CO.: LaGrange (1 mi. N). 1 female, 4 males, S.M. Fullerton; LaGrange (3 mi. N). 2 males, Mar. 26, 1960, S.M. Fullerton.

\section{INDEX OF SPECIES NAMES}

This index consists of all Latin names of generic and specific standing currently being used or placed in synonymy and listed in alphabetical order so that the reader can readily find each name. Specific epithets in italics are currently recognized names, those in standard type are considered to be synonyms. The numbers in bold-face refer the reader to the page where the name appears in the description of the species or in the synonymy listed on that page. Numbers in plain text refer the reader to the pages of the keys to species or to the page where the name appears on a map.

baeriae Timberlake

$5,6,14,15$.

compositarum, new species

$5,6,20,22$.

dissona, new species

$5,6,19,20$.

duboisi Timberlake

$4,5,9,10$.

eremophila, new species

$5,15,21$.

escondida Cockerell $5,6,9$.

Hesperandrena 2.

lativentris Timberlake 4, 6, 1215.

leucomystax, new species

4, 5, 17, 20.

limnanthis Timberlake 8. pulverea Viereck 


\section{BIBLIOGRAPHY}

Bouseman, J.K., and W.E. LaBerge 1979. A revision of the bees of the genus Andrena of the Western Hemisphere. Part IX. Subgenus Melandrena. Trans. Am. Entomol. Soc., 104:275-389.

Cockerell, T.D.A. 1938. Descriptions and records of bees.- CLXIX. Ann. Mag. Nat. Hist., (11)2:14

Donovan, B.J. 1977. A revision of North American bees of the subgenus Cnemidandrena (Hymenoptera: Andrenidae). Univ. Calif. Publ. Entomol., 81: $1-107$.

Goodpasture, C.E. 1974. Cytological data and classification of the Hymenoptera. $\mathrm{Ph}$. D. Dissertation. Univ. California at Davis.

LaBerge, W.E. 1964. Prodromus of American bees of the genus Andrena. Bull. Univ. Neb. State Mus., 4(14):279-316.

-1967. A revision of the bees of the genus Andrena of the Western Hemisphere. Part I. Callandrena. Univ. Neb. State. Mus. Bul., 7:1-316.

- 1969. A revision of the bees of the genus Andrena of the Western Hemisphere. Part II. Plastandrena, Aporandrena, Charitandrena. Trans. Am. Entomol. Soc., 95:1-47. 1971. A revision of the bees of the genus Andrena of the Western Hemisphere. Part. IV. Scrapteropsis, Xiphandrena, and Rhaphandrena. Trans. Am. Entomol. Soc., 97:441-520.

. 1973. A revision of the bees of the genus Andrena of the Western Hemisphere. Part VI. Subgenus Trachandrena. Trans. Am. Entomol. Soc., 99:235-371.

. 1977. A revision of the bees of the genus Andrena of the Western Hemisphere. Part VIII. Subgenera Thysandrena, Dasyandrena, Psammandrena, Rhacandrena, Euandrena, Oxyandrena. Trans. Am. Entomol. Soc., 103:1-143.

. 1980. A revision of the bees of the genus Andrena of the Western Hemisphere. Part X. Subgenus Andrena. Trans. Am. Entomol. Soc., 106:395525.

. 1986. A revision of the bees of the genus Andrena of the Western Hemisphere. Part XI. Minor subgenera and subgeneric key. Trans. Am. Entomol. Soc., 111:441-567.

. 1987. A revision of the bees of the genus Andrena of the Western Hemisphere. Part XII. Subgenera Leucandrena, Ptilandrena, Scoliandrena, and Melandrena. Trans. Am. Entomol. Soc., 112:191-248.

-1989. A revision of the bees of the genus Andrena of the Western Hemisphere. Part XIII. Subgenera Simandrena and Taeniandrena. Trans. Am. Entomol. Soc., 115:1-56.

LaBerge, W.E., and J.K. Bouseman 1970. A revision of the bees of the genus Andrena in the Western Hemisphere. Part III. Tylandrena. Trans. Am. Entomol. Soc., 96:543-605.

- 1977. On the systematic position of three black Andrena from Western North America (Hymenoptera: Andrenidae). J. Kans. Entomol. Soc., 50:601-612.

LaBerge W.E., and D.W. Ribble 1972. A revision of the bees of the genus Andrena of the Western Hemisphere. Part IV. Gonandrena, Geissandrena, Parandrena, Pelicandrena. Trans. Am. Entomol. Soc., 98:271-358. 
1975. A revision of the bees of the genus Andrena of the Western Hemisphere. Part VII. Subgenus Euandrena. Trans. Am. Entomol. Soc., 101:371-446.

Lanham, U.N. 1949. A subgeneric classification of the New World bees of the Genus Andrena. Univ. Calif. Publ. Entomol., 8:183-238.

Leong, J.M. and R.W. Thorp. 1999. Colour-coded sampling: the pantrap colour Preferences of olgiolectic and nonoligolectic bees associated with a vernal pool plant. Ecol. Entomol., 24:329-335.

Rust, R., A. Menke and D. Miller. 1985. A bibliographic comparison of the bees, Sphecid wasps and mealy bugs of the California Channel Islands, U. S. A. Proc. 1st Symposium, Santa Barbara Mus. Nat. Hist., 1:29-60.

Skinner, M.W. and B.M. Pavlik, eds. 1994. Inventory of rare and endangered vascular plants of California. California Native Plant Society, Spec. Publ. No. 1, 5th ed., Sacramento, CA. 336 pp.

Thorp, R.W. 1969. Systematics and ecology of bees of the subgenus Diandrena (Hymenoptera: Andrenidae). Univ. Calif. Publ. Entomol., 52:1-146.

Thorp, R.W. 1976. Insect pollination of vernal pool flowers. Pp. 36-40. In S. Jain, ed. Vernal Pools, Their Ecology and Conservation. Symposium Institute of Ecology, University of California, Davis. Publication No. 9, 93 pp.

Thorp, R.W. 1990. Vernal pool flowers and host specific bees. Pp. 109-122. In Ikeda, D.H. and R.A. Schlising, eds. Vernal Pool Plants: Their Habitat and Biology. Studies from the Herbarium, No. 8. California State University at Chico, 178 pp.

Thorp, R.W. and J.M. Leong. 1995. Native bee pollinators of showy vernal pool Plants. Fremontia, 23(2):3-7.

Thorp, R.W. and J.M. Leong. 1998. Specialist bee pollinators of showy vernal pool flowers. Pp. 169-179. In C.W. Witham, E.T. Bauder, D. Belk, W.R. Ferren, Jr., and R. Ornduff, eds. Ecology, Conservation and Management of Vernal Pool Ecosystems. Proceedings from a 1996 Conference. California Native Plant Society, Sacramento, CA. 285 pp.

Timberlake, R.H. In U. N. Lanham, 1949. A subgeneric classification of the New World bees of the genus Andrena. Univ. Calif. Publ. Entomol., p. 386.

- 1951. New and little-known bees of the family Andrenidae from California. Proc. U.S. Nat. Mus., 101:373-414.

Viereck, H.L. 1917. Andrena of Canadian, Alleghanian and Carolinian plant zones occurring or likely to occur in Connecticut. Trans. Am. Entomol. Soc., 43:365-407. 


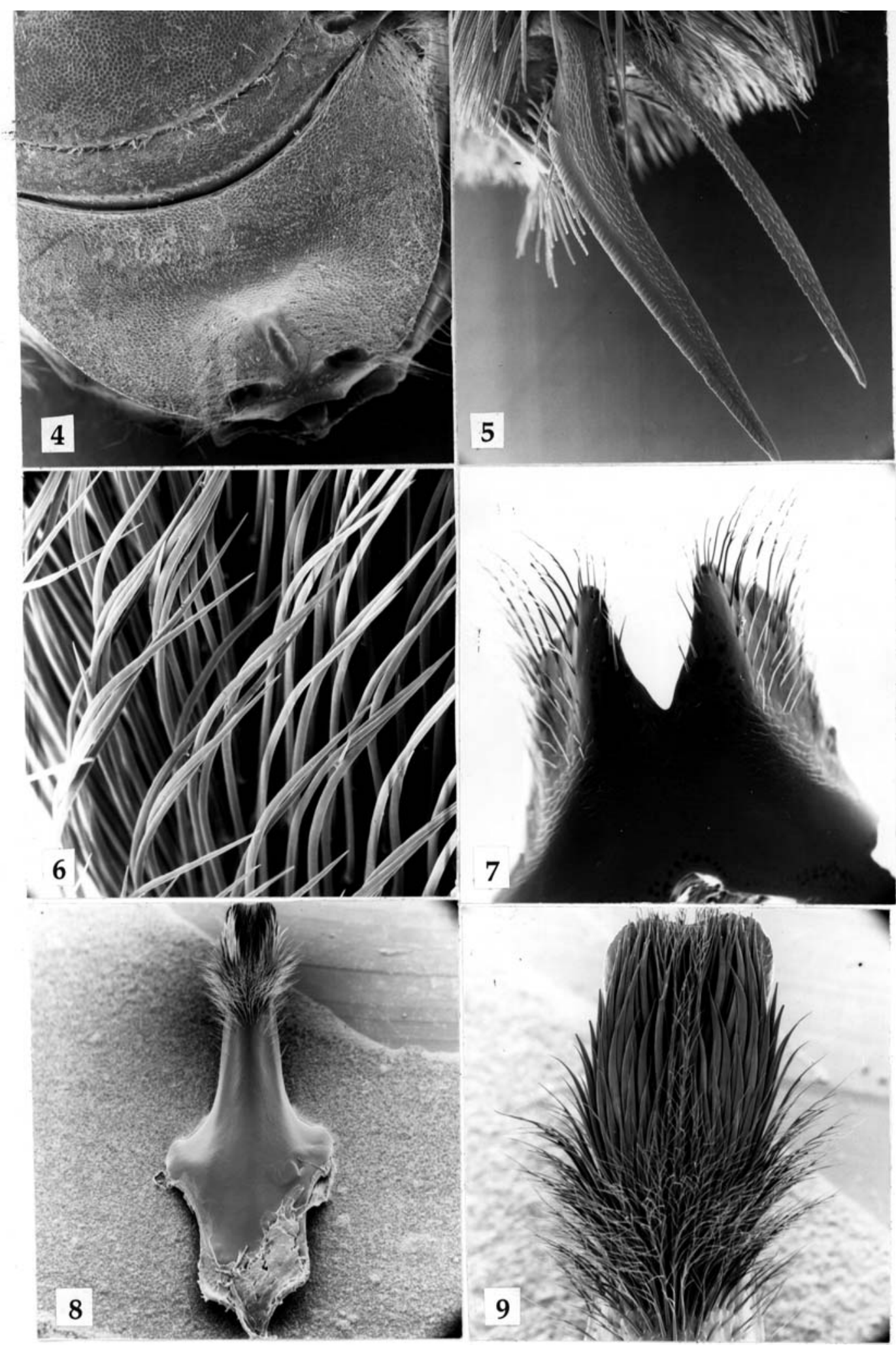

Figs 4-9. Andrena pulverea Viereck: 4-Male propodeum, dorsal view, note the lateral carinae extending most of the length on each side, X 30. 5-Female hind tibial spurs, note posterior spur broadened toward base, X 100. 6-Female central scopal hairs, X 100. 7- Male sternum 7, dorsal view, X 100. 8-Male sternum 8, X 100. 9-Male tip of sternum 8, enlarged, note flattened, spearlike hairs in apical half of neck region with plumose hairs basally, across tip and in thin line down middle, X150. 


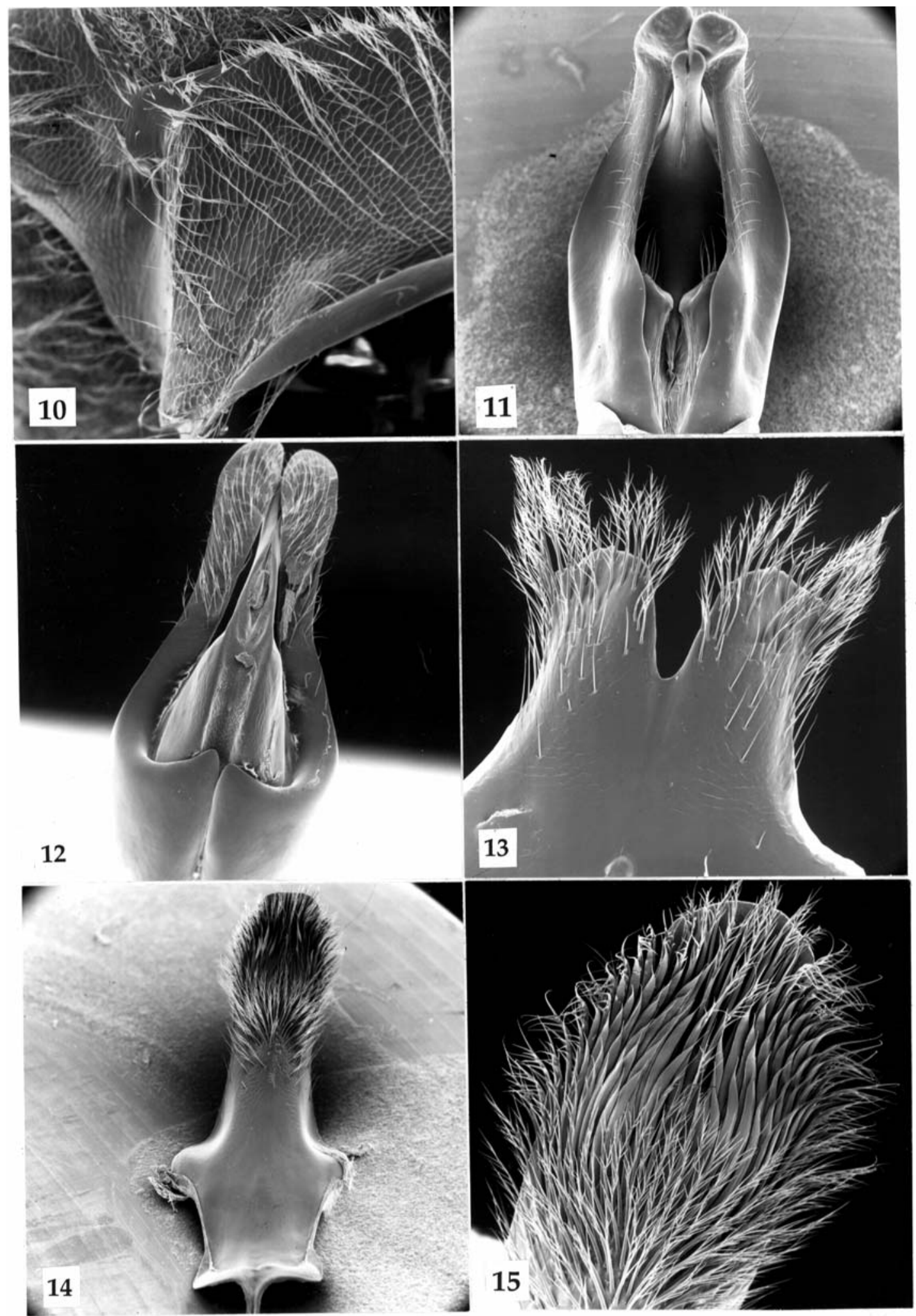

Figs. 10-15. Andrena baeriae Timberlake: 10-Male pronotum from above and slightly from anterior; note sharp dorsoventral ridge and rounded dorsolateral angle, X 70. 11Male genital capsule, ventral view, X 30. 12-Male genital capsule, dorsal view, X 30. 13-Male sternum 7, X 100. 14-Male sternum 8, X 100. 15-Male tip of sternum 8, note flattened hairs as in Fig. 8, X 150. 


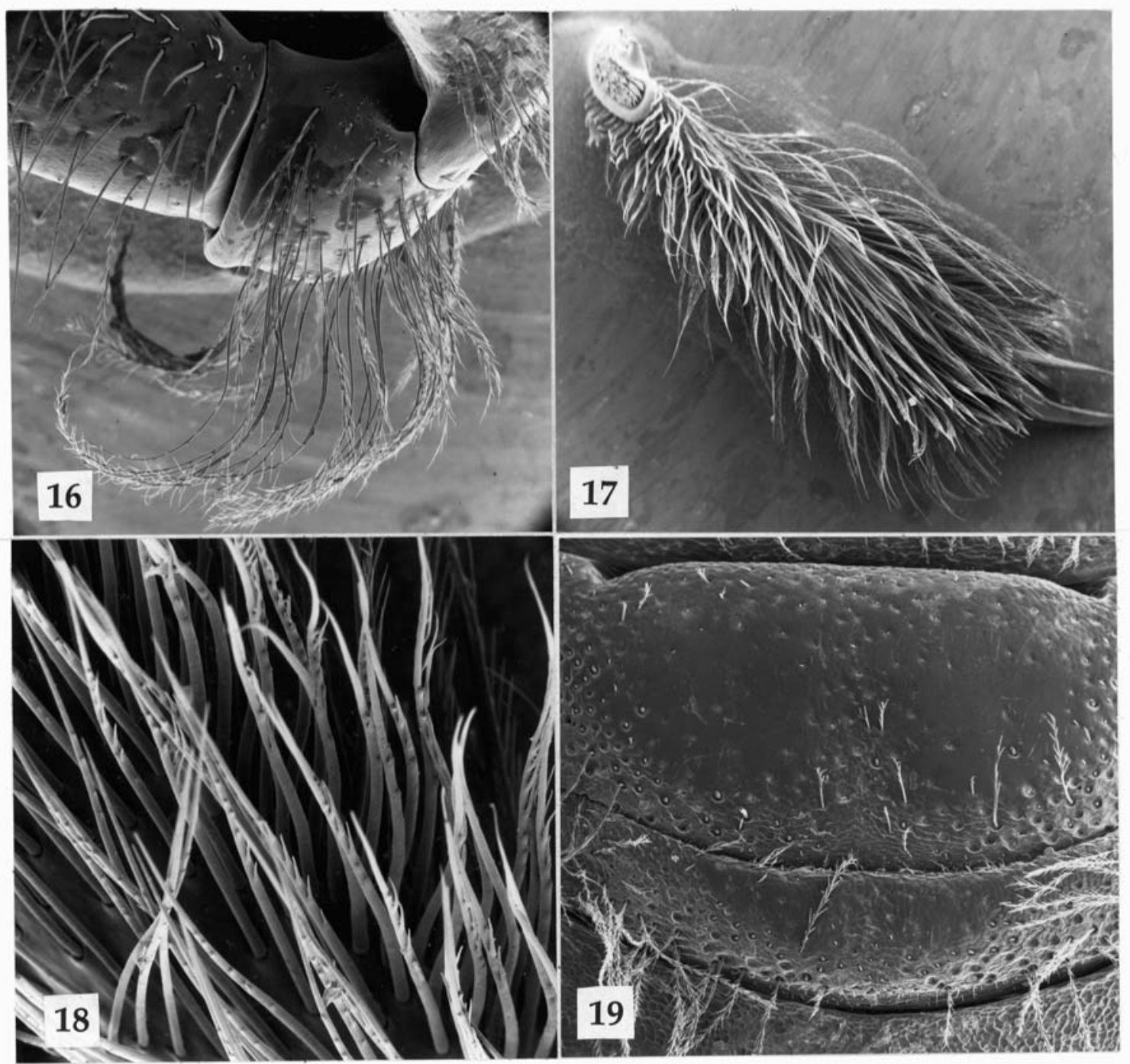

Figs. 16-19. Andrena leucomystax, new species: 16-Female posterior hind leg showing trochanter and trochanteral flocculus, X 50. 17-Female right leg showing scopa, X 30 . 18-Female showing scopal hairs enlarged, note weak plumosity, X 100. 19-Female scutellum and metascutum, dorsal aspect, X 70. 


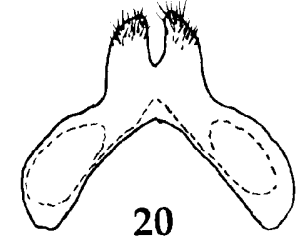

20

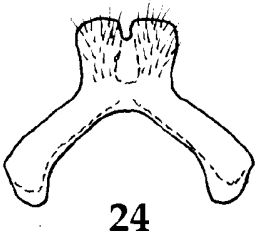

24

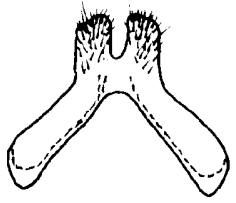

28

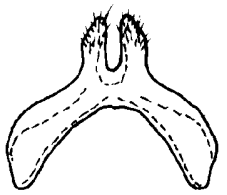

32

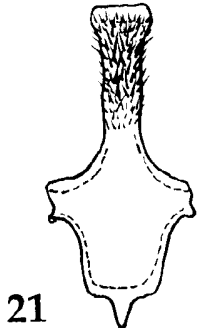

25
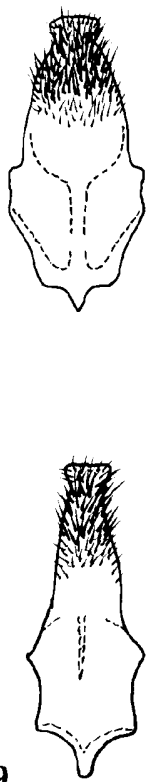

29

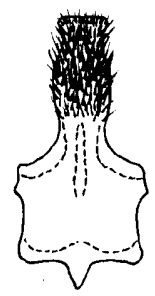

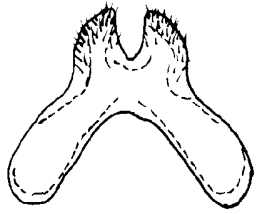

22

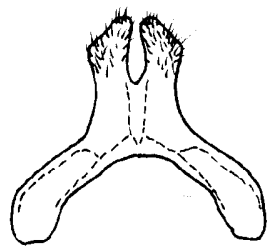

26

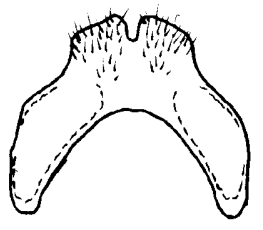

30

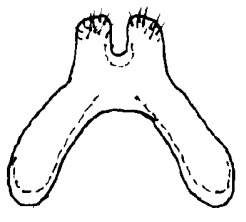

34
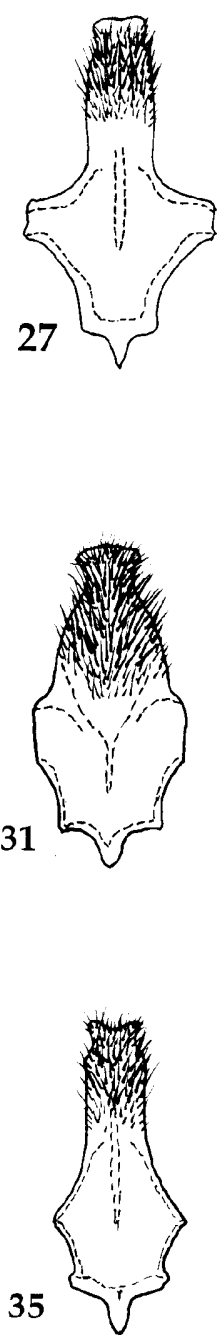

Figs. 20-35. Sterna 7 and 8 of males of species of Andrena subgenus Hesperandrena: 20-21-A. escondida Cockerall. 22-23-A. pulverea Viereck. 24-25-A. duboisi Viereck. 26-27-A. lativentris Timberlake. 28-29-A. baeriae Timberlake. 30-31-A. leucomystax, Thorp and LaBerge. 32-33-A. dissona Thorp and LaBerge. 34-35-A. eremophila Thorp and LaBerge. 


Illinois Natural History Survey

Natural Resources Building

607 East Peabody Drive

Champaign, Illinois 61820

217-333-6880

A Division of the Illinois Department of Natural Resources

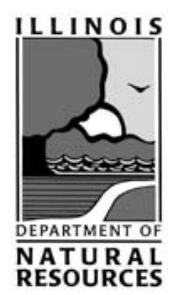

